\title{
Genomic, Microbial and Immunological Microenvironment of Colorectal Polyps
}

\author{
Benita C. Y. Tse ${ }^{1}$, Zoe Welham ${ }^{1}$, Alexander F. Engel ${ }^{2,3}$ and Mark P. Molloy ${ }^{1, *(1)}$ \\ 1 Bowel Cancer and Biomarker Laboratory, Faculty of Medicine and Health, School of Medical Sciences, \\ The University of Sydney, Sydney 2006, Australia; benita.tse@sydney.edu.au (B.C.Y.T.); \\ zwel5671@uni.sydney.edu.au (Z.W.) \\ 2 Department of Colorectal Surgery, Royal North Shore Hospital, Sydney 2065, Australia; \\ alexander.engel@sydney.edu.au \\ 3 Faculty of Medicine and Health, Northern Clinical School, The University of Sydney, Sydney 2006, Australia \\ * Correspondence: m.molloy@sydney.edu.au; Tel.: +61-299-267-870
}

check for updates

Citation: Tse, B.C.Y.; Welham, Z.; Engel, A.F.; Molloy, M.P. Genomic, Microbial and Immunological Microenvironment of Colorectal Polyps. Cancers 2021, 13, 3382. https://doi.org/10.3390/ cancers 13143382

Academic Editor: David A. Geller

Received: 21 May 2021

Accepted: 1 July 2021

Published: 6 July 2021

Publisher's Note: MDPI stays neutral with regard to jurisdictional claims in published maps and institutional affiliations.

Copyright: (c) 2021 by the authors. Licensee MDPI, Basel, Switzerland. This article is an open access article distributed under the terms and conditions of the Creative Commons Attribution (CC BY) license (https:// creativecommons.org/licenses/by/ $4.0 /)$.
Simple Summary: Colorectal cancers (CRC) initiate from small cell clusters known as polyps. Colonoscopic surveillance and removal of polyps is an important strategy to prevent CRC progression. Recent advances in sequencing technologies have highlighted genetic mutations in polyps that potentially contribute to CRC development. However, CRC might be considered more than a genetic disease, as emerging evidence describes early changes to immune surveillance and gut microbiota in people with polyps. Here, we review the molecular landscape of colorectal polyps, considering their genomic, microbial and immunological features, and discuss the potential clinical utility of these data.

Abstract: Colorectal cancer (CRC) develops from pre-cancerous cellular lesions in the gut epithelium, known as polyps. Polyps themselves arise through the accumulation of mutations that disrupt the function of key tumour suppressor genes, activate proto-oncogenes and allow proliferation in an environment where immune control has been compromised. Consequently, colonoscopic surveillance and polypectomy are central pillars of cancer control strategies. Recent advances in genomic sequencing technologies have enhanced our knowledge of key driver mutations in polyp lesions that likely contribute to CRC. In accordance with the prognostic significance of Immunoscores for CRC survival, there is also a likely role for early immunological changes in polyps, including an increase in regulatory $\mathrm{T}$ cells and a decrease in mature dendritic cell numbers. Gut microbiotas are under increasing research interest for their potential contribution to CRC evolution, and changes in the gut microbiome have been reported from analyses of adenomas. Given that early changes to molecular components of bowel polyps may have a direct impact on cancer development and/or act as indicators of early disease, we review the molecular landscape of colorectal polyps, with an emphasis on immunological and microbial alterations occurring in the gut and propose the potential clinical utility of these data.

Keywords: colorectal polyps; adenoma; colorectal carcinoma; microbiome; immunogenic; mutational burden; colonoscopy

\section{Introduction}

Colorectal cancer (CRC) is the second most common cancer in females and third most common in males. Currently accounting for $10 \%$ of all new cancer diagnoses a year and 700,000 deaths worldwide, CRC incidence is expected to continue to increase [1]. It has been well established that the development of sporadic CRC begins with precursor growths in the lining of the bowel epithelium, known as polyps. Neoplastic polyps harbor malignant potential due to loss of function of tumour suppressor genes and/or activation of driver proto-oncogenes [2]. 
In sporadic CRC, two major genetic pathways underlying CRC progression from polyps have been described: (i) the conventional adenoma-carcinoma pathway, and (ii) the serrated neoplasia pathway. The conventional adenoma pathway accounts for approximately $70 \%$ of CRCs and is defined by loss of function mutation in the $\mathrm{Wnt} /$ beta catenin pathway regulator gene $A P C$, typically followed by activating mutations of the KRAS oncogene, leading to a chromosomal instability (CIN) genotype of microsatellite stable CRC [1]. Histologically, tubular adenoma, tubulovillous adenoma and villous adenoma are subtypes genetically driven through the conventional CIN pathway, they and represent the most frequent polyps found in the colorectum. In comparison, the alternative genetic route is known as the serrated neoplasia pathway that accounts for the remaining $\sim 30 \%$ of CRC. Within this pathway, sessile serrated adenoma/polyps (SSA/P) are characterised by $B R A F$ mutations and high levels of CpG island methylator phenotype (CIMP) [3,4]. Epigenetic silencing of $M L H 1$ in some SSA/P results in deficient mismatch repair and high microsatellite instability (MSI-H), allowing for the accumulation of numerous advantageous mutations that facilitate dysplasia and carcinogenesis. Notably, epigenetic silencing of tumour suppressor genes other than MLH1 can occur in SSA/P, resulting in CIMP-high, microsatellite stable CRCs. SSA/P are observed with greater frequency in the proximal colon. Traditional serrated adenomas (TSA) are lowly prevalent, genetically heterogeneous lesions typically observed in the distal colon and rectum. TSAs can harbor KRAS or BRAF mutations, or neither, and can be CIMP-low or high, and are microsatellite stable. MLH1 is rarely under epigenetic silencing in TSA, although MGMT may be hypermethylated, eliminating the repair of adducted DNA. [3,5,6].

MicroRNA (miRNA) are small, single-stranded non-coding RNAs that contribute to health and disease through post-transcriptional gene regulation. miRNAs have been identified to play key roles in CRC carcinogenesis through regulating a plethora of genes involving oncogenic signaling pathways, including Wnt, Ras, transforming growth factor beta (TGF- $\beta$ ) and NF-KB/AKT/STAT3, as well as other regulatory pathways such as stemness, epithelial-mesenchymal transition and metastasis [7-17]. Readers are referred to reviews describing how miRNA contributes to CRC carcinogenesis [18-20].

The major genetic alterations underlying conventional adenomas and serrated lesions are now well-established. Next generation sequencing (NGS) is enabling even deeper discovery of the mutational profiles within polyp subtypes. However, CRC is more than a genetic disease, and understanding how microbial and immune activity contributes to CRC's progression at the pre-malignant polyp stage is important to gain a more holistic understanding and identify new prevention and treatment strategies. The purpose of this review is to summarise our understanding of the genomic burdens, immune activity and microbiomes associated with sporadic colorectal polyps (Figure 1). 


\begin{tabular}{|lll|l|l|}
\cline { 2 - 5 } \multicolumn{1}{c|}{} & \multicolumn{1}{c|}{ CAD } & SSA & TSA \\
\hline
\end{tabular}

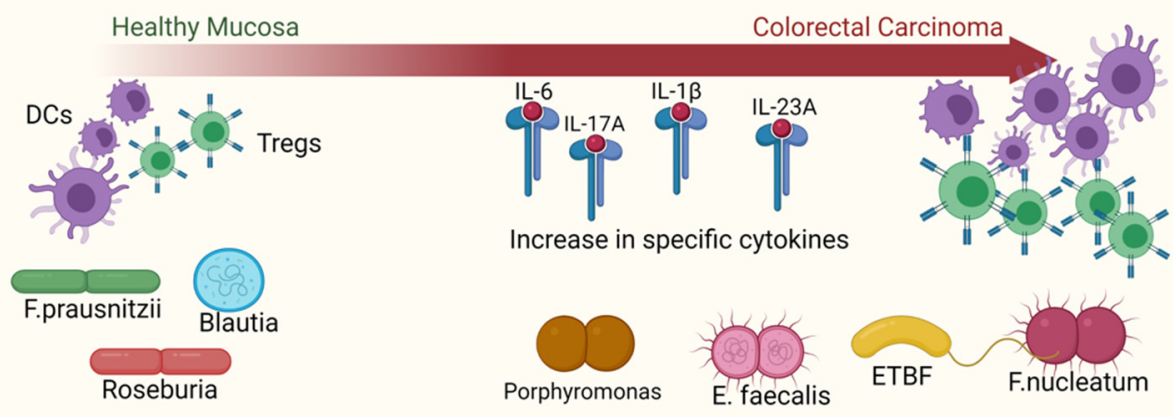

Figure 1. The progression of colorectal polyps to adenocarcinoma is multi-factorial, with different polyp subtypes showing patterns in their genetic, immune and microbiome features. Genetic environment: conventional adenomas (CAD) are characterised by chromosomal instability (CIN) and show early mutations in the adenomatous polyposis coli (APC) and KRAS genes, with dysregulated Wnt, RAS, PI3K, p53 and TGF- $\beta$ intracellular pathways. Commonly driven by BRAF V600E mutation and with disruptions in Wnt/ $\beta$-catenin signalling pathways, serrated sessile adenomas (SSAs) show aberrant methylation, (CIMP+) and can be MSI-high or MSS. Traditional serrated adenomas (TSAs) can have either BRAF or KRAS mutations, RNF43 inactivation and often show R-spondin gene fusions. They may be either CIMP-low or CIMP-high. Immune environment: progression from polyps to carcinoma is correlated with a decrease in the ratio of mature dendritic cells to immature dendritic cells (DCs), as well as an increase in the relative number of regulatory $\mathrm{T}$ cells (Tregs). Increases in pro-inflammatory cytokines such as IL-6, IL-17A, IL-1 $\beta$ and IL-23A are reported. Microbiome environment: relative to healthy tissue, mucosal polyps and carcinoma have altered microbial communities such as decreases in F. prausnitzii, Roseburia and Blautia, and an increased relative abundance of bacteria including enterotoxic Bacteroides fragilis (ETBF), E. faecalis and F. nucleatum.

\section{Gene Mutations in Colorectal Polyps}

Advancements in NGS have revealed detailed new molecular data, cataloguing the key driver and passenger mutations associated with colorectal adenocarcinoma and their precursor adenoma and SSA/P lesions. Nikolaev and colleagues examined early CRC carcinogenesis, and their seminal work using whole-exome sequencing of 24 colorectal adenomas demonstrated that these pre-cancers exhibited a 'mutator phenotype' of high, single nucleotide substitutions compared to non-transformed cells, which was enabled through inactivation of a gene responsible for genomic stability, proposed to be APC [21]. Consistent with the Vogelstein model of stepwise accumulation of driver mutations in the transition of conventional adenoma to adenocarcinoma, Zhou and colleagues applied exome capture sequencing of 73 pairs of matched adenoma and adenocarcinoma samples, showing higher numbers of nonsynonymous somatic single nucleotide variations in adenocarcinomas compared to adenomas [22]. Whole-exome sequencing and targeted sequencing of 149 polyp samples showed that serrated adenomas and conventional adenomas had similar frequencies of somatic mutations, but with distinctive driver mutations consistent with their differing genetic origins [23]. Combined, exome-wide studies of conventional adenomas reveal that APC, KRAS, PIK3CA, TP53 and SMAD4 genes affecting Wnt, RAS, $\mathrm{PI} 3 \mathrm{~K}, \mathrm{p} 53$ and TGF-beta signaling pathways are amongst those most commonly altered, of- 
ten with significantly increasing mutation prevalence in development from non-advanced conventional adenomas to advanced conventional adenomas to CRC [23-28].

In contrast to conventional adenomas, BRAF V600E is the most highly prevalent driver for SSA/P neoplasia. In a study of 234 polyps, $B R A F$ mutations were detected in $81-92 \%$ of SSA/P subtypes and only $0-9 \%$ of these lesions had KRAS mutations. KRAS and $B R A F$ mutations were always mutually exclusive [29]. Mutational inactivation of the E3 ubiquitin-protein ligase RNF43 is common in SSA/P, and often co-occurs with BRAF and is absent in tubulovillous/villous adenoma [30,31]. However, the mutational frequency of RNF43 inactivation in sporadic disease varies across studies, serrated lesion subtype and degree of dysplasia [32]. Similar variation has been reported for APC in SSA/Ps (low in SSA/P without dysplasia > dysplastic SSA/P > TSAs) $[33,34]$. TSA are the least common type of colorectal serrated polyp and show considerable molecular diversity. Sequencing of 128 TSAs showed $97 \%$ harboured mutations in MAPK pathway genes (predominantly $B R A F$ V600E or KRAS) and $84 \%$ had mutations in WNT pathway genes [35]. Among WNT pathway genes, R-Spondin (RSPO) gene fusions and overexpression is frequently observed [36].

\section{Tumour Mutational Burden}

The growing ease and rapidity of NGS molecular profiling has grown the idea of tumour mutational burden (TMB) as a facile clinical biomarker, especially for predicting response to immunotherapies [37]. The field is yet to settle on a standard for measuring $\mathrm{TMB}$, with growing interests evaluating use of more cost-effective panel sequencing in place of whole exome sequencing (WES) [38]. Additionally, approaches to mutation calling and TMB quantification remain challenging in samples with low tumor content, while defining cut-points for discriminating high versus low TMB appears to be study-specific. [39]. Nonetheless, in advanced melanoma, non-small cell lung carcinoma, urothelial cancer, renal cancer and others, high TMB is commonly reported to be predictive for response to immune checkpoint immunotherapy and improved overall survival (OS) [40-47]. In CRC, patients with deficient mismatch repair, MSI-H tumours showing high TMB and treated with the programmed cell death protein 1 (PD-1) inhibitor pembrolizumab as first-line monotherapy showed significantly improved progression-free survival compared to standard of care chemotherapy with or without bevacizumab or cetuximab [48]. In a trial evaluating the benefit of adding bevacizumab or cetuximab to oxaliplatin- or irinotecanbased chemotherapy, microsatellite stable (MSS) colorectal tumours classified as high TMB $(>8 / \mathrm{Mb})$ compared to low TMB achieved limited, but longer median overall survival (33.8 months versus 28.1 months), while no differences were observed between treatment arms. It was hypothesised that higher TMB tumours would possess increased lymphocyte infiltration, and this may be a factor in the survival outcomes [49]. As a prognostic factor, the clinical utility of TMB in different cancer types is still to be resolved. Nonetheless, several studies using different methodologies for determining TMB and high/low cutpoints have reported that higher TMB is associated with worse survival for colorectal cancer patients who do not receive immune checkpoint inhibitors [50-52].

The clinical utility of measuring mutational burdens in the pre-cancer setting of colorectal polyps is yet to be established. Nonetheless, several emerging studies mentioned below provide data to investigate this prospect. WES of 25 colorectal adenomas and 10 matched adjacent mucosas from familial adenomatous polyposis patients reported a mutation frequency of 1.75 mutations per $\mathrm{Mb}$ of exome sequence in polyps, while non-hypermutated adenocarcinomas had a mean of 4.26 mutations/Mb [53]. Lin and colleagues used WES to establish an average non-silent somatic mutation rate of $1.6 / \mathrm{Mb}$ for sporadic adenomas compared to $4.6 / \mathrm{Mb}$ for non-hypermutated CRC samples in The Cancer Genome Atlas (TCGA) database [23]. Non-significant differences in mutational burden were reported when comparing conventional adenomas and SSA/Ps $(1.5$ and $1.7 / \mathrm{Mb}$, respectively). In this cohort, small differences were reported between non-advanced and advanced adenomas (1.6 and 2.0/Mb, respectively). More recently, an examination of 
58 large conventional adenomas with low and high grade dysplasia, using an alternative approach of panel sequencing of 409 cancer genes, reported a mean nonsynonymous variant rate of $8.0 / \mathrm{Mb}$ compared to $8.8 / \mathrm{Mb}$ for these genes in adenocarcinomas from the TCGA CRC dataset [54]. These studies demonstrate that TMB differences between polyps and adenocarcinomas are observed using either WES or gene panel sequencing. What is currently lacking is an assessment of whether the variations in mutational burden and mutation patterns seen within adenomas reflect functional differences, such as malignancy risk or metastatic potential, either of which could have important clinical value. It is likely that polyps of clinical concern would be the TMB outlier cases (i.e., adenomas with TMB similar to those measured for CRCs). Perhaps the combination of histological findings and polyp mutational burdens would contribute to a more informative prognostic risk score by taking into consideration mutations in oncogenic drivers. This score is missing in current clinical practice risk assessments and might be informative for the timing of surveillance colonoscopies.

\section{Immunological Environment within Polyps}

Cancer development involves continuous cross-talk between malignant cells and the immune system in a process known as cancer immunoediting. The adaptive immune system eliminates highly immunogenic tumours $[55,56]$ and controls tumour cells with lower immunogenicity until spontaneously advantageous mutations allow for escape from immune control [57]. Thus, the type, function, density and location of immune cells within tumour regions have been extensively studied. In CRC, this concept enabled the establishment of the 'Immunoscore', whereby cancers are graded based on the densities of pan-T cells and cytotoxic $\mathrm{T}$ cells $[58,59]$. CRC patients with high densities of lymphocyte infiltrate have increased overall survival and reduced tumour recurrence $[60,61]$. Despite the Immunoscore being a better predictor of CRC recurrence and survival than histopathological features [60], relatively little is known about the immune contexture of pre-cancerous colorectal polyps.

The immunological environment within colorectal polyps is largely driven by the developmental pathways. SSA/Ps with microsatellite instability (MSI) have high accumulated mutational burden and appear to be highly immunogenic. Acosta-Gonzalez and colleagues showed that the sequential progression of SSA/Ps through low-grade to high-grade dysplasia was paired with increasing density of intraepithelial lymphocytes and increasing expression of checkpoint inhibitors PD-1 and its ligand PD-L1 [62]. In comparison to cancers arising from conventional adenomas, cancers arising from SSA/Ps have greater numbers of tumour-infiltrating lymphocytes (TILs), at least in part supported by a high number of Crohn's-like reactions. These TILs act as local tertiary lymphoid structures that facilitate lymphocyte recruitment and expansion [63]. Elevated TILs and Crohn's-like reactions are associated with MSI. Murakami et al. note their observations are consistent with a tumour-related immune response in SSA/Ps, where malignancy develops in the presence of amplified TILs and Crohn's-like reactions.

Immunohistochemical analyses reveal that conventional adenomas have decreased numbers of mature dendritic cells whilst showing increasing numbers of immature dendritic cells compared to mucosa of healthy controls [64]. The reduction in number of mature dendritic cells continues as conventional adenomas progress to cancer [64]. As mature dendritic cells are responsible for presenting antigens, as well as activating adaptive immune cells, the lack of mature dendritic cells suggests an inability to generate tumour antigen-specific immune responses. This observation is consistent with a reduction in the expression of antigen presentation molecule, human leukocyte antigen-DR (HLA-DR), in both the epithelium and stroma of colorectal carcinomas compared to matched adenomas [65]. A decrease in HLA-DR expression in the stroma was also observed in the progression from early stage to late-stage carcinomas, which may have wider implications for immunotherapeutic development. 
Similarly, other signs of a dampened immune response can be observed in conventional adenomas. An increase in mucosal cyclooxygenase-2 (COX-2) mRNA has been reported in the progression of colorectal adenomas to cancers [64]. Activation of COX-2 leads to the production of immune suppressive molecules such as prostaglandin E2. COX-2 expression and HER-2 have previously been described as important regulators of CRC invasion and metastasis [66]. In addition to COX-2, the mRNA expression of costimulatory molecules CD80 and CD86 was altered in polyp patients compared to control patients. Required for effective activation of $\mathrm{T}$ cell receptors and subsequent cell-mediated immunity, the expression of CD86 was higher within polyp tissue whilst CD80 expression was reduced [67].

Regulatory T cells accumulate within colorectal tumours and are immune suppressive by inhibiting the transepithelial migration $[68,69]$, activation [70] and proliferation of effector T cells [71]. Together, they suppress the anti-colorectal tumour immune response in a COX-2-dependent manner [72]. The number of intraepithelial regulatory T cells was observed to increase when adenomatous polyps with low-grade dysplasia were compared to advanced adenomas and CRCs [73,74]. Interestingly, this accumulation appears specific to sporadic adenomas and has not been reported in familial adenomatous polyposis [75]. The accumulation of regulatory $\mathrm{T}$ cells in colorectal adenomas was equivalent to CRCs and associated with an increase in expression of FoxP3 and IL-10 [76]. Furthermore, the increase in regulatory $\mathrm{T}$ cells could be observed in peripheral blood of patients with colorectal polyps (either serrated adenomas or conventional adenoma polyps), whereby regulatory T cells consisted of $2.9 \%$ of all circulating lymphocytes [77]. This is higher than patients without polyps (at 1.8\%) but lower than patients with CRC (at 12.6\%). However, this is at least in part due to an overall increase in peripheral helper $\mathrm{T}$ cell frequency during CRC progression [77]. In addition to changes in peripheral frequencies, it should be noted that regulatory $\mathrm{T}$ cells from polyp patients and CRC patients showed varying expressions of some genes. In particular, only CRC peripheral regulatory $\mathrm{T}$ cells expressed the immune suppressive cytokine IL-10, whilst only polyp regulatory T cells had significantly lower expression of the IL-10 receptor $\alpha$ [77]. This suggests that regulatory T cell function changes throughout CRC progression.

There remain many immune cell subsets whose presence in, and/or influence on, colorectal polyps is not well defined (Table 1). For example, whilst regulatory $\mathrm{T}$ cells have been explored, less is known about other subsets of T cells. However, studies investigating cytokine expression hint at the associated phenotype changes. IL-17A is a cytokine typically produced by Th17 cells, and an increase in the expression of IL-17A can be seen in the adenoma-carcinoma sequence [78]. In particular, IL-17A mRNA levels in colorectal adenomas increase with the severity of dysplasia and can be detected in adjacent tissues $[78,79]$. In combination with an associated increase in its receptor, IL-17 receptor A [80], and other Th17-inducing cytokines such as IL-23A, IL-1 $\beta$ and IL-6 in colorectal adenomas [79], Th17 cells may have an important role in defining the immune microenvironment in early CRC development. Colorectal adenomas also show increased expression of Th1-associated cytokines (IFN- $\gamma$, TNF- $\alpha$, IL-12A, IL-18) compared to normal mucosa and CRC [81]. More in-depth analyses of $\mathrm{T}$ cell subsets within colorectal adenomas are warranted in the future, especially given that CRC patients with higher expression of Th1-related genes show prolonged disease-free survival, whilst patients with high expression of Th17-associated genes have poorer prognoses [82]. Hence, the Th1/Th17 ratio within colorectal adenomas may be an important early prognostic indicator. Indeed, these cytokine changes are not only local but can be seen in the serum, where systemic increases in IFN- $\gamma$, IL-4, IL-5 and IL-12 have been reported in colorectal adenoma patients compared to controls [83]. In particular, the increases in serum IL-4 are consistent with CRC patients, whereby increases are associated with higher CRC staging [84]. This suggests that some of these $\mathrm{T}$ cell changes are systemic immune responses to colorectal adenomas, but this requires further investigation.

Similarly, many innate immune cells are known to be altered in CRC and/or observed in mouse models (e.g., $\mathrm{APC}^{\mathrm{min} /+}$ ), but are poorly explored in human polyps. Investigations 
into macrophages within colorectal polyps are warranted given that high macrophage infiltration is associated with improved survival [85] and reduced liver metastasis in CRC [86]. Neutrophil infiltration on the tumour front also indicates better patient prognosis in Stage I-II CRC [87]. Conversely, CRCs have reduced numbers of natural killer cells in comparison to normal mucosa, and those patients with high NK tumour infiltration achieve better overall survival $[88,89]$. Mouse models of colorectal adenoma and carcinoma offer insight into the importance and influence of myeloid cells in polyp development. In the APC ${ }^{\mathrm{min} /+}$ model of FAP, Stat 6 was found to be a mediator of polyp development, at least in part by promoting the expansion of myeloid-derived suppressor cells (MDSCs) in the lamina propria [90]. In the same model, the chemokine CCL2 was found to promote the accumulation and immune suppressive capabilities of MDSCs in polyps [91]. The authors also noted increases in CCL2 levels within the colitis-associated CRC and adenomas of patients, suggesting that CCL2 may play a role in human CRC development. Similarly, invariant natural killer T (iNKT) cells are reduced in number within $\mathrm{APC}^{\mathrm{min} /+}$ mouse polyps [92]. Deletion of iNKT in these mice or reducing iNKT cell frequency by treatment of cell ligands led to a reduction in polyp burden [92,93], again suggesting a role of iNKTs in polyp development. It is important to note, however, that sporadic colorectal adenomas in humans are genetically complex and heterogeneous (as mentioned above). Hence, the $\mathrm{APC}^{\mathrm{min} /+}$ model offers insight, but not necessarily evidence, for the role of these myeloid cells in human colorectal adenoma.

Given that the location of immune cells within the cancer environment and their interaction with other immune cells dictate the immune response and the overall survival of patients [94], more in-depth analyses of immune cell subsets in the early stages of CRC development may have important prognostic value. A major limitation of previous investigations has been the one to two marker immunohistochemical stains for immunophenotyping; this limitation restricts the ability to accurately define subsets and immune cell interactions. Therefore, use of newer multiplexed capabilities will allow more in-depth phenotyping of immune cells, which is required to gain a deeper understanding of their frequency and role in the progression of CRC.

Table 1. Comparison of known immune cell associations with human polyps and CRC.

\begin{tabular}{|c|c|c|}
\hline Immune Cell Subset & Associations in Polyps & Associations in CRC \\
\hline $\mathrm{T}$ cells & & $\begin{array}{l}\text { T cell numbers in the tumour centre are associated with } \\
\text { improved disease-free survival [95]. }\end{array}$ \\
\hline Cytotoxic T cells & & $\begin{array}{c}\text { Cytotoxic T cells in the tumour centre are associated } \\
\text { with improved disease-free survival and overall } \\
\text { survival }[95,96] .\end{array}$ \\
\hline Helper T cells & & $\begin{array}{c}\text { High expression of Th1-related genes is associated with } \\
\text { increased disease-free survival, whilst a high expression } \\
\text { of Th17-related genes is associated with poor } \\
\text { prognosis [82]. }\end{array}$ \\
\hline Regulatory T cells & $\begin{array}{l}\text { Increases in number with } \\
\text { malignant transformation } \\
\qquad[73,74] .\end{array}$ & $\begin{array}{c}\text { Increase in number in tumour compared to normal } \\
\text { mucosa [97]. High infiltrate within the tumour stroma } \\
\text { and centre is associated with improved overall } \\
\text { survival }[95,96] .\end{array}$ \\
\hline Mucosa-associated invariant $\mathrm{T}$ cells & & Accumulate in tumour tissue irrespective of stage [98]. \\
\hline Natural killer T cells & & $\begin{array}{c}\text { Increase in number in CRC. Patients with high natural } \\
\text { killer T cell infiltration associated with better overall } \\
\text { survival [99]. }\end{array}$ \\
\hline
\end{tabular}


Table 1. Cont.

\begin{tabular}{|c|c|c|}
\hline Immune Cell Subset & Associations in Polyps & Associations in CRC \\
\hline B cells & & $\begin{array}{l}\text { Higher numbers of infiltrating B cells seen in tumours of } \\
\text { the right colon and associated with better disease-free } \\
\text { survival [100]. }\end{array}$ \\
\hline Dendritic cells & $\begin{array}{l}\text { Reduced numbers of mature } \\
\text { dendritic cells and increased } \\
\text { numbers of immature } \\
\text { dendritic cells seen in } \\
\text { conventional adenomas [64]. }\end{array}$ & $\begin{array}{l}\text { Infiltration of dendritic cells is higher in MSI-H lesions } \\
\text { [101]. Improved survival of patients with high } \\
\text { infiltration of dendritic cells [102]. }\end{array}$ \\
\hline Macrophages & & $\begin{array}{l}\text { High macrophage infiltration is associated with } \\
\text { improved survival in colon cancer and reduced liver } \\
\text { metastasis }[85,86] \text {. }\end{array}$ \\
\hline Neutrophils & & $\begin{array}{l}\text { High neutrophil infiltration in the tumour front is } \\
\text { associated with better prognosis in patients with stage } \\
\text { I-II CRC [87]. }\end{array}$ \\
\hline Natural killer cells & & $\begin{array}{c}\text { CRCs contain fewer natural killer cells than adjacent } \\
\text { normal mucosa [88]. Patients with extensive natural } \\
\text { killer cell infiltration have higher rates of overall } \\
\text { survival [89]. }\end{array}$ \\
\hline
\end{tabular}

\section{Microbiota and Colorectal Polyps}

Gut microbiota represent a diverse ecosystem consisting of several trillion bacteria that perform important health functions for the host. Species composition between individuals is varied [103], which may be due to host genetics, diet, exercise, alcohol and smoking habits, as well as early life microbial exposure [104-106]. Microbiota in the human gut are predominantly anaerobes, with the two phyla Firmicutes and Bacteroidetes comprising $90 \%$ of the community, and the phyla Actinobacteria, Proteobacteria, Fusobacteria and Verrucomicrobia comprising the majority of the remainder [107]. Through improvements to analytical technologies, it has become evident that changes to the gut microbiome are observed along the axis of CRC carcinogenesis: healthy-neoplastic-malignant mucosa [108]. Most studies investigating the gut microbiome use faecal analysis as a convenient proxy for sampling the bowel, while fewer studies directly measure colonic mucosal microbiota. This is an important distinction, as mucosal microbiota directly interacts with mucins and receptors on the cell surface at specific gut locations, while microbiota in stools represent those transported in the intestinal lumen $[109,110]$. Given that some bacterial pathogens have toxins that can cause oncogenic transformation (e.g., $\mathrm{pks}^{+}$E. coli) [111], and others have been commonly localised with colorectal tumours (i.e., Fusobacterium spp.), it is of interest to have wider knowledge of the microbes associated with neoplastic colorectal lesions.

One of the first studies to examine bowel-polyp-associated microbiota [112] used terminal restriction fragment length polymorphism (T-RFLP) to compare normal rectal mucosal biopsies from patients with and without adenomas. Moreover, 16S rRNA sequencing of four adenoma and four controls (non-polyp patients) showed enrichment of Proteobacteria and depletion of Bacteroidetes in adenomas compared to controls, while the phylum Firmicutes was similar in both groups. However, amongst the Firmicutes, adenoma cases showed a relative increase in Faecalibacterium spp. and Dorea spp., and a relative decrease in Bacteroides spp. and Coprococcus spp.

Magnifesta and colleagues [113] directly compared polyp mucosa with healthy marginal tissue from 12 polyp cases consisting of proximal tubular adenomas and rectal hyperplastic polyps. They found no overall changes at the phylum level, but they did observe enrichment of specific bacteria such as Lactobacillus, Helicobacter and Klebsiella, and a relative depletion of bacteria, including Bifidobacterium, Faecalibacterium, Eschericia- 
Shigella, Bacteroides, Blautia and Lachnoclostridium, in polyp mucosa compared to adjacent healthy tissue. Similar results were reported by Sanarpeddy and colleagues [114], with relative increases in Lactobacillus and Helicobacter, in addition to other genera, in 33 adenoma cases compared to controls. Recently, Wang et al. [115] compared biopsy samples from 49 advanced adenomas (AA) (mean size $>=10 \mathrm{~mm}$ ) with adjacent normal mucosa, and 36 healthy control samples. AA mucosa showed enrichment of Proteobacteria phyla and depletion of Firmicutes and Bacteroidetes phyla compared to healthy controls. More specifically, bacteria from the Oceanospirillales family and Shewanella algae showed enrichment, while Blautia, Coprococcus, Bacteroides and Faecalibacterium prausnitzii were depleted. Contrary to other reports, Fusobacterium were depleted in AA cases compared to healthy controls.

Dadkhah and colleagues [116] used a machine learning approach to compare $138 \mathrm{mu}-$ cosa, 183 stool and 231 rectal swab samples of adenoma cases (including non-neoplastic polyps, benign ( $50 \%)$, advanced $(2 \%)$ and high-risk adenomas $(21 \%))$ with healthy controls. Overall, they reported a lower abundance of Proteobacteria in polyp cases compared to controls. In addition, the genera Bifidobacterium, Faecalibacterium and Blautia were depleted in adenoma mucosa samples compared to control mucosa but, at the species level, there was no enrichment of the pathogens Fusobacterium nucleatum and B. fragilis.

A study comparing the microbiome and metabolome reported significant enrichment of Bifidobacterium, as well as a trend towards enrichment for Escherichia coli, Clostridium and Bacteroides, in 15 adenoma cases compared to 15 healthy controls [117]. Moreover, 23 metabolites were associated with differences between adenoma and control cases. In particular, there was an increase in inflammatory metabolite prostaglandin E2 and a decrease in antioxidant metabolites 5-oxoproline and diketogulonic acid in adenoma cases compared to controls. These metabolites were associated with inflammatory responses, carbohydrate metabolism and GI disease pathways.

Fusobacterium nucleatum, a notable oral microbe, has previously been indicated in colorectal pathogenesis [118]. McCoy and colleagues [119] used qPCR to determine that F. nucleatum was significantly enriched in the rectal mucosa of 48 adenoma patients compared to 67 healthy controls. This agrees with Kostic and colleagues [120], who reported enrichment of Fusobacterium spp. in adenomas relative to adjacent tissues, and in stool samples from colorectal adenoma and carcinoma patients compared to healthy subjects. Ito and colleagues [121] also used qPCR to compare Fusobacterium in formalin-fixed paraffinembedded (FFPE) tissues of 343 sessile serrated adenomas, 122 conventional adenomas and 511 CRC cases. F. nucleatum was commonly detected but could not sufficiently differentiate between these pathologies: $24 \%$ of HPs, $35 \%$ of SSAs, $30 \%$ of TSAs and $33 \%$ of non-serrated adenoma showed high F. nucleatum. In particular, F. nucleatum was more frequent in CIMP-high lesions and was positively correlated with grade. The inability of $F$. nucleatum to parse differences between SSA and conventional adenomas was also reported by Yoon [122]; however, with only six samples per group, these findings need clarification with sufficient statistical power.

In summary, the above studies demonstrate that, like CRC, colorectal adenomas commonly harbor an altered microbiome compared to healthy mucosa. Whether this is cause or effect remains a matter of much debate $[123,124]$. Key findings from analyses of bowel polyp mucosa (Table 2) suggest a relative enrichment of bacteria from the phylum Proteobacteria, particularly the orders Pseudomonodales (e.g., genus Pseudomonas), Enterobacterales (e.g., genera Escherichia-Shigella, Klebsellia) and Campylobacterales (e.g., genus Helicobacter) in adenoma cases compared to controls. There is also relative enrichment from the phylum Firmicutes, predominantly class Bacilli (e.g., Lactobacillus and Lactococcus), in adenoma cases compared to controls. Consistent with the previous literature, Fusobacterium species were often found to be enriched in adenoma cases compared to controls. In contrast, some Firmicutes bacteria tend to be depleted in adenoma cases compared to controls, particularly from class Clostridia (e.g., Blautia, Faecalibacterium and Bacilli). This is also the case with genera from phyla Actinobacteria (e.g., Bifidobacterium) and Bacteroidetes 
(e.g., Bacteroides). However, it must be noted that reports were not always consistent. For example, some studies showed a trend towards depletion in bacteria in adenoma cases from Fusobacteria taxa, as well as from phylum Proteobacteria (e.g., Escherichia coli, Escherichia-Shigella) and Firmicutes (e.g., Lactobacillus) that were commonly reported to be enriched in other studies.

Although these studies highlight some recurrent and differentially abundant species, they also report many bacteria that are specific for each study. This may be influenced by large inter-individual microbiome composition differences at the genera and species levels [125], or may be an artefact of the different bioinformatic analysis pipelines employed. Either way, the choice of 16S rRNA primer selection as a limitation to reliably discriminate bacteria at the species level [126] could contribute to differences in bacterial taxonomy assignment. However, this variability in identified species also highlights the importance of understanding their functional role, as the interplay between bacteria and metabolite production is complex [127]. Both human and mouse models suggest that the adenoma microbiome is characterised by a decrease in butyrate-producing bacteria (e.g., Faecalibacterium prausnitzii), which show a protective effect on gut permeability and inflammation and an increase in bacteria that increase epithelial permeability and inflammation, produce reactive oxygen species and damage DNA [128]. It is not well understood which bacteria induce these early processes. A more comprehensive approach, currently missing from studies in bowel polyps, would be to utilise whole genome shotgun metagenomic sequencing, which can incorporate functional analysis with species-level identification. Together with larger sample sizes for increased statistical power, this approach may clarify which bacteria are involved in these processes.

Table 2. Studies examining microbiomes from human gut mucosal adenomas.

\begin{tabular}{|c|c|c|c|c|}
\hline Study & Subjects & Method & $\begin{array}{c}\text { Families and Genera Enriched } \\
\text { in Adenoma }\end{array}$ & $\begin{array}{c}\text { Families and Genera Depleted } \\
\text { in Adenoma }\end{array}$ \\
\hline $\begin{array}{l}\text { Shen et al. } \\
\text { [112] }\end{array}$ & $4 \mathrm{CA}, 4 \mathrm{HC}$ & $\begin{array}{l}\text { T-RFLP, } \\
\text { 16S rRNA }\end{array}$ & Dorea, Faecalibacterium & Bacteroides, Coprococcus \\
\hline $\begin{array}{l}\text { Mira-Pascual et al. } \\
\text { [129] }\end{array}$ & $11 \mathrm{CA}, 7 \mathrm{CRC}, 10 \mathrm{HC}$ & V1-V3 16S rRNA & $\begin{array}{c}\text { Akkermansia, Bifidobacterium, } \\
\text { Blautia, Enterobacteriaceae, } \\
\text { Fusobacterium }\end{array}$ & Faecalibacterium \\
\hline $\begin{array}{l}\text { Dadkhah et al. } \\
\text { [116] }\end{array}$ & $122 \mathrm{CA}$ & V1-V2 16S rRNA & & $\begin{array}{l}\text { Bifidobacterium, Blautia, } \\
\text { Faecalibacterium }\end{array}$ \\
\hline $\begin{array}{l}\text { Sanarpeddy et al. } \\
{[114]}\end{array}$ & $33 \mathrm{CA}, 38 \mathrm{HC}$ & V1-V2 16S rRNA & $\begin{array}{c}\text { Acidovorax, Aquabacterium, } \\
\text { Cloacibacterium, Helicobacter, } \\
\text { Lactobacillus, Lactococcus, } \\
\text { Pseudomonas }\end{array}$ & Streptococcus \\
\hline $\begin{array}{l}\text { Lu et al. } \\
\text { [130] }\end{array}$ & $31 \mathrm{CA}, 20 \mathrm{HC}$ & V3-V4 16S rRNA & Lactococcus, Pseudomonas & Bacillus, Enterococcus, Solibacillus \\
\hline $\begin{array}{l}\text { Nugent et al. } \\
\text { [117] }\end{array}$ & $15 \mathrm{CA}, 15 \mathrm{HC}$ & MS, qPCR & Bifidobacterium, Eubacteria & \\
\hline $\begin{array}{c}\text { Mangifesta et al. } \\
\text { [113] }\end{array}$ & $12 \mathrm{CA}$ & V3 16S rRNA & $\begin{array}{l}\text { Helicobacter, Lactobacillus, } \\
\text { Klebsiella, Prevotella }\end{array}$ & $\begin{array}{c}\text { Bacteroides, Bifidobacterium, } \\
\text { Blautia, Escherichia-Shigella, } \\
\text { Faecalibacterium, Romboutsia, } \\
\text { Ruminococcaceae }\end{array}$ \\
\hline $\begin{array}{l}\text { Wang et al. } \\
\text { [115] }\end{array}$ & 49 Advanced-CA, $36 \mathrm{HC}$ & V4 16S rRNA & $\begin{array}{c}\text { Halomonas, Oceanospirillales, } \\
\text { Shewanella algae }\end{array}$ & $\begin{array}{c}\text { Bacteroides, Blautia, Coprococcus, } \\
\text { Fusobacterium }\end{array}$ \\
\hline $\begin{array}{l}\text { Kostic et al. } \\
\quad[120]\end{array}$ & $28 \mathrm{CA}, 27 \mathrm{CRC}, 31 \mathrm{HC}$ & qPCR & Fusobacterium & \\
\hline $\begin{array}{l}\text { McCoy et al. } \\
\text { [119] }\end{array}$ & $48 \mathrm{CA}, 67 \mathrm{HC}$ & qPCR & Fusobacterium & \\
\hline $\begin{array}{l}\text { Ito et al. } \\
\text { [121] }\end{array}$ & $\begin{array}{l}343 \text { SSA, } 122 \text { CA, } 511 \\
\text { CRC }\end{array}$ & qPCR & Fusobacterium nucleatum & \\
\hline
\end{tabular}

$\mathrm{CA}=$ colorectal adenoma, $\mathrm{CRC}=$ colorectal carcinoma, $\mathrm{HC}=$ healthy control, $\mathrm{qPCR}=$ quantitative polymerase chain reaction, $\mathrm{MS}=$ mass spectrometry. 


\section{Interaction of Microbiota and the Immune System in CRC Tumorigenesis}

Microbiota have a role in the development and regulation of the host immune system, including regulating inflammation, which is associated with increased risk of CRC [131-133]. The intersection of microbes and immune-regulated mucosal inflammation is linked to bowel tumorigenesis. For example, mouse studies have shown the importance of CD4+ helper T cells and Foxp3+ Tregs secretion of IL-10 to control intra-polyp inflammation and growth in a polyposis-prone APC disruption model [134]. Depleting IL-10 resulted in a fivefold increase in colonic polyps and alterations to epithelial barrier integrity that enabled the expansion of pathogenic bacteria Bacteroides and Porphyromonas within colonic polyps compared to healthy mucosa. Broad spectrum antibiotics attenuated inflammation and polyposis, establishing a clear link between microbes, inflammation and tumouriogenesis. Using germ-free APC ${ }^{\mathrm{min} /+} ; \mathrm{IL}_{10}^{-/-}$, Tobin and colleagues found alternative microbes in stool that positively correlated with increased tumour numbers in mice exposed to specific pathogen-free bacteria, namely Akkermansia, Blautia, Dorea, Enterococcus and Escherichia/Shigella; however, altered levels of Bacteroides and Porphyromonas were not found [135]. Interestingly, there was no correlation with bacteria and tumourigenesis in $\mathrm{APC}$ min/+ mice that retained IL-10 secretion, underscoring the importance of immune-microbiota interactions. Enterococcus faecalis, in addition to promoting superoxide and hydrogen peroxide-induced DNA damage [136], is associated with increased NF-KB-mediated pro-inflammatory cytokine (IL-6 and IP-10) gene expression in IL-10-deficient mice [137]. Enterotoxic Bacteroides fragilis (ETBF), in addition to inducing bowel mucosa permeability [138], can induce carcinogenesis in $\mathrm{APC} \mathrm{min}^{/+}$mice through the activation of a Stat3-driven TH17 response, with the blockade of IL-17 resulting in the inhibition of ETBF-induced tumours [139]. ETBF also enhanced Treg-initiated IL-17mediated carcinogenesis in C57BL/6 FOXP3 ${ }^{\mathrm{DTR}}$ mice [140]. In addition to its activity as an oncomir [141], and utilising its virulence factor FadA to infiltrate epithelial cells and activate proliferation pathways [142], F. nucleatum can recruit tumour-infiltrating immune cells in APC ${ }^{\mathrm{min} /+}$ mice, resulting in upregulated pro-inflammatory genes [120]. F. nucleatum can also inhibit $\mathrm{T}$ cell activation and NK-mediated killing of tumour cells [143]. Other bacteria indicated in inflammation-mediated colon carcinogenesis include Streptococcus gallolyticus [144] and pks+-harbouring Escherichia coli, which are indicated in ROS production and induce macrophage COX-2 and prostaglandin E2 pro-carcinoma activities [145].

Overall, dysbiotic bacterial degradation of the mucosal barrier, as well as its disruption of the tight junctions that lie between the lumen of the bowel and its underlying stroma, is thought to allow infiltration of bacteria and their metabolites; in turn, this process induces the recruitment of innate and adaptive immune cells [146] (Figure 2). Bacterial engagement with Toll-like receptors (TLRs) and nucleotide-binding oligomerization domain-like receptors (NLRs) on immune cells may then induce pro-inflammatory cytokines [26,147], as well as reactive oxygen and nitrogen species (RONS) [148]. This inflammation response can result in DNA damage and CIN, as well as impairment of the Wnt/ $\beta$-catenin and base excision repair (BER) pathways, thus resulting in increased risk for cell proliferation, angiogenesis and metastasis $[128,149]$. 


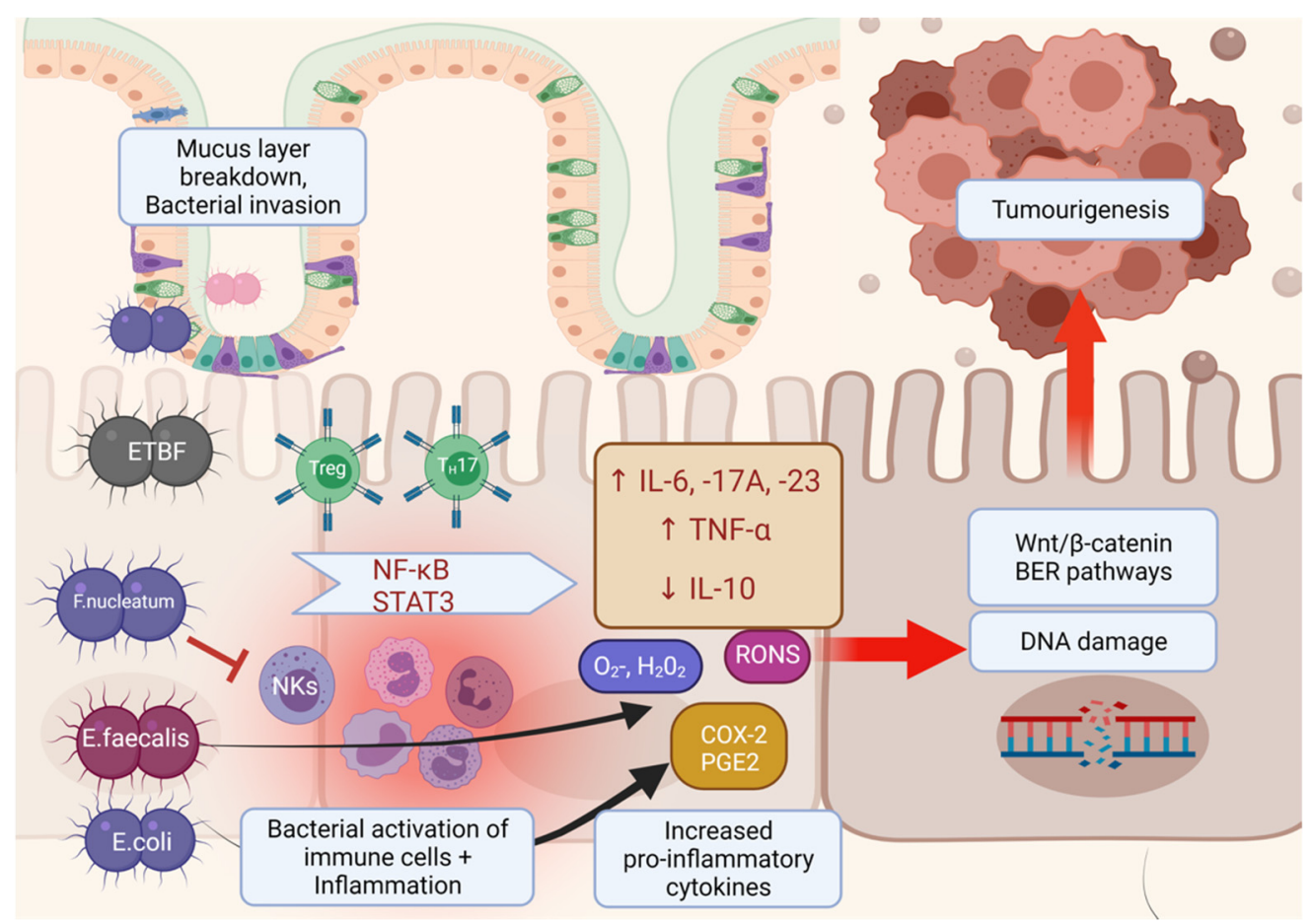

Figure 2. Interactions of immune response with gut microbiome facilitate CRC carcinogenesis. Dysbiosis of commensal bowel bacteria may compromise colonic epithelial barrier integrity, allowing pathogenic bacteria and their metabolites entry into the underlying stroma and promoting immune cell-mediated pro-inflammatory cytokine responses. In particular, E.faecalis is associated with NF-кB-mediated pro-inflammatory IL-6 and IP-10 gene expression. F.nucleatum is associated with IL-17A and TNF- $\alpha$ expression, as well as inhibiting T cell activation and natural killer cells (NKs). The presence of ETBF in the mucosa is correlated with Treg-induced Th17 production of IL-17A. Pks+-harbouring Escherichia coli is associated with COX-2 and PGE-2 pro-carcinoma responses. These pro-inflammatory responses can induce DNA damage and the induction of the Wnt/ $\beta$-catenin and base excision repair (BER) pathways, thus increasing the risk of cell proliferation, transformation into carcinoma and subsequent metastasis.

\section{Potential Clinical Uses of Polyp Molecular Characteristics}

A greater understanding of the molecular landscapes defining premalignant colorectal lesions may reveal new opportunities to prevent CRC and alter the management of patients with a history of bowel polyps. We envisage a potential use of such molecular information to augment disease risk assessment and better optimise colonoscopy surveillance interval timing. For example, in cases where small adenomas $(5-10 \mathrm{~mm})$ show elevated mutational burden, such molecular data, combined with histology and clinical history, may warrant earlier colonoscopic surveillance than current guidelines suggest. Conversely, an argument could be made to extend surveillance timing in the case of a single larger polyp (e.g., $10-20 \mathrm{~mm}$ ) that shows low mutational burden and an absence of key oncogenic drivers, such as APC, KRAS or BRAF. In a similar vein, gut microbiomes measured non-invasively from stool samples may have utility in identifying colonic polyps in patients with a history of such lesions. This would have considerable positive impacts on delivering colonoscopy services, as most screening procedures currently lead to negative findings.

How specific immune content in polyps relates to disease prognosis is still in its infancy. Even in a broader sense, immune content has yet to be utilised for cancer staging, despite its obvious importance for determining response to immunotherapies [59]. However, in CRC, use of the $\mathrm{CD}^{+} / \mathrm{CD}^{+}$Immunoscore as a simple measure of TILs has been shown to be prognostic for disease-free survival and overall survival [60]. Immune cell content of colorectal polyps may similarly have prognostic value and alter patient surveillance management, as described above. A further idea to investigate centres on 
maintaining/restoring immunosurveillance capabilities through identifying new treatment targets directed at the immune infiltrate as a primary mechanism of tumour control.

\section{Conclusions}

Large-scale NGS efforts have demonstrated that subtypes of premalignant colorectal polyps contain specific genetic lesions that establish genetic instability and/or microsatellite instability. The progression of these precursor lesions to tumours occurs with the disruption of immune control and may be facilitated by interaction with gut pathogens and a state of gut microbial dysbiosis. The combination of histology, tumour mutation burden, microbiome and immune cell infiltrates will provide a clearer understanding of the molecular progression of bowel polyps to cancers, but additional research is needed to comprehensively unravel the complex intersection of molecular effectors underlying colorectal tumorigenesis. The combination of these molecular factors provides a multifaceted approach for assessing individual patient risk, with the potential to optimise colonoscopy surveillance intervals and reduce the number of negative colonoscopies conducted, without compromising patient health.

Author Contributions: Writing original draft, review, editing, preparation, B.C.Y.T.; writing original draft, review, editing, Z.W.; review, editing, A.F.E.; conceptualization, writing original draft, review, editing, preparation, M.P.M. All authors have read and agreed to the published version of the manuscript.

Funding: This research was funded by Cancer Council NSW (RG20-10), Tour de Cure (RSP-222-2020), Garry Whyte Sea Angel Trust and Bowel Cancer Research Foundation Australia.

Acknowledgments: The authors thank Jennifer White for administrative assistance.

Conflicts of Interest: The authors declare no conflict of interest.

\section{References}

1. Dekker, E.; Tanis, P.J.; Vleugels, J.L.A.; Kasi, P.M.; Wallace, M.B. Colorectal cancer. Lancet (Lond. Engl.) 2019, 394, 1467-1480. [CrossRef]

2. Shussman, N.; Wexner, S.D. Colorectal polyps and polyposis syndromes. Gastroenterol. Rep. 2014, 2, 1-15. [CrossRef] [PubMed]

3. Bettington, M.; Walker, N.; Clouston, A.; Brown, I.; Leggett, B.; Whitehall, V. The serrated pathway to colorectal carcinoma: Current concepts and challenges. Histopathology 2013, 62, 367-386. [CrossRef]

4. Leggett, B.; Whitehall, V. Role of the serrated pathway in colorectal cancer pathogenesis. Gastroenterology 2010, 138, 2088-2100. [CrossRef]

5. Pai, R.K.; Bettington, M.; Srivastava, A.; Rosty, C. An update on the morphology and molecular pathology of serrated colorectal polyps and associated carcinomas. Mod. Pathol. 2019, 32, 1390-1415. [CrossRef] [PubMed]

6. De Palma, F.D.E.; D'Argenio, V.; Pol, J.; Kroemer, G.; Maiuri, M.C.; Salvatore, F. The molecular hallmarks of the serrated pathway in colorectal cancer. Cancers 2019, 11, 1017. [CrossRef]

7. Aherne, S.T.; Madden, S.F.; Hughes, D.J.; Pardini, B.; Naccarati, A.; Levy, M.; Vodicka, P.; Neary, P.; Dowling, P.; Clynes, M. Circulating miRNAs miR-34a and miR-150 associated with colorectal cancer progression. BMC Cancer 2015, 15, 329. [CrossRef] [PubMed]

8. Gattolliat, C.H.; Uguen, A.; Pesson, M.; Trillet, K.; Simon, B.; Doucet, L.; Robaszkiewicz, M.; Corcos, L. MicroRNA and targeted mRNA expression profiling analysis in human colorectal adenomas and adenocarcinomas. Eur. J. Cancer 2015, 51, 409-420. [CrossRef]

9. Kamatani, A.; Nakagawa, Y.; Akao, Y.; Maruyama, N.; Nagasaka, M.; Shibata, T.; Tahara, T.; Hirata, I. Downregulation of anti-oncomirs miR-143/145 cluster occurs before APC gene aberration in the development of colorectal tumors. Med. Mol. Morphol. 2013, 46, 166-171. [CrossRef]

10. Kanaan, Z.; Barnett, R.; Gardner, S.; Keskey, B.; Druen, D.; Billeter, A.; Cheadle, W.G. Differential microRNA (miRNA) expression could explain microbial tolerance in a novel chronic peritonitis model. Innate Immun. 2013, 19, 203-212. [CrossRef]

11. Nagel, R.; le Sage, C.; Diosdado, B.; van der Waal, M.; Oude Vrielink, J.A.; Bolijn, A.; Meijer, G.A.; Agami, R. Regulation of the adenomatous polyposis coli gene by the miR-135 family in colorectal cancer. Cancer Res. 2008, 68, 5795-5802. [CrossRef] [PubMed]

12. Oberg, A.L.; French, A.J.; Sarver, A.L.; Subramanian, S.; Morlan, B.W.; Riska, S.M.; Borralho, P.M.; Cunningham, J.M.; Boardman, L.A.; Wang, L.; et al. miRNA expression in colon polyps provides evidence for a multihit model of colon cancer. PLoS ONE 2011, 6, e20465. [CrossRef] [PubMed] 
13. Uratani, R.; Toiyama, Y.; Kitajima, T.; Kawamura, M.; Hiro, J.; Kobayashi, M.; Tanaka, K.; Inoue, Y.; Mohri, Y.; Mori, T.; et al. Diagnostic Potential of Cell-Free and Exosomal MicroRNAs in the identification of patients with high-risk colorectal adenomas. PLOS ONE 2016, 11, e0160722. [CrossRef] [PubMed]

14. Zhang, J.; Raju, G.S.; Chang, D.W.; Lin, S.H.; Chen, Z.; Wu, X. Global and targeted circulating microRNA profiling of colorectal adenoma and colorectal cancer. Cancer 2018, 124, 785-796. [CrossRef] [PubMed]

15. Bartley, A.N.; Yao, H.; Barkoh, B.A.; Ivan, C.; Mishra, B.M.; Rashid, A.; Calin, G.A.; Luthra, R.; Hamilton, S.R. Complex patterns of altered MicroRNA expression during the adenoma-adenocarcinoma sequence for microsatellite-stable colorectal cancer. Clin. Cancer Res. 2011, 17, 7283-7293. [CrossRef]

16. Slattery, M.L.; Herrick, J.S.; Wolff, R.K.; Mullany, L.E.; Stevens, J.R.; Samowitz, W. The miRNA landscape of colorectal polyps. Genes Chromosomes Cancer 2017, 56, 347-353. [CrossRef]

17. Tsikitis, V.L.; Potter, A.; Mori, M.; Buckmeier, J.A.; Preece, C.R.; Harrington, C.A.; Bartley, A.N.; Bhattacharyya, A.K.; Hamilton, S.R.; Lance, M.P.; et al. MicroRNA signatures of colonic polyps on screening and histology. Cancer Prev. Res. 2016, 9, 942-949. [CrossRef]

18. Strubberg, A.M.; Madison, B.B. MicroRNAs in the etiology of colorectal cancer: Pathways and clinical implications. Dis. Models Mech. 2017, 10, 197-214. [CrossRef]

19. Guo, Y.; Bao, Y.; Yang, W. Regulatory miRNAs in colorectal carcinogenesis and metastasis. Int. J. Mol. Sci. 2017, 18, 890. [CrossRef]

20. Anvarnia, A.; Mohaddes-Gharamaleki, F.; Asadi, M.; Akbari, M.; Yousefi, B.; Shanehbandi, D. Dysregulated microRNAs in colorectal carcinogenesis: New insight to cell survival and apoptosis regulation. J. Cell Physiol. 2019, 234, 21683-21693. [CrossRef]

21. Nikolaev, S.I.; Sotiriou, S.K.; Pateras, I.S.; Santoni, F.; Sougioultzis, S.; Edgren, H.; Almusa, H.; Robyr, D.; Guipponi, M.; Saarela, J.; et al. A single-nucleotide substitution mutator phenotype revealed by exome sequencing of human colon adenomas. Cancer Res. 2012, 72, 6279-6289. [CrossRef]

22. Zhou, D.; Yang, L.; Zheng, L.; Ge, W.; Li, D.; Zhang, Y.; Hu, X.; Gao, Z.; Xu, J.; Huang, Y.; et al. Exome capture sequencing of adenoma reveals genetic alterations in multiple cellular pathways at the early stage of colorectal tumorigenesis. PLoS ONE 2013, 8, e53310. [CrossRef]

23. Lin, S.H.; Raju, G.S.; Huff, C.; Ye, Y.; Gu, J.; Chen, J.S.; Hildebrandt, M.A.T.; Liang, H.; Menter, D.G.; Morris, J.; et al. The somatic mutation landscape of premalignant colorectal adenoma. Gut 2018, 67, 1299-1305. [CrossRef]

24. Lee, S.H.; Yoo, J.; Song, Y.S.; Lim, C.H.; Kim, T.M. Mutation analysis of colorectal and gastric carcinomas originating from adenomas: Insights into genomic evolution associated with malignant progression. Cancers 2020, 12, 325. [CrossRef]

25. Vaqué, J.P.; Martínez, N.; Varela, I.; Fernández, F.; Mayorga, M.; Derdak, S.; Beltrán, S.; Moreno, T.; Almaraz, C.; De Las Heras, G.; et al. Colorectal adenomas contain multiple somatic mutations that do not coincide with synchronous adenocarcinoma specimens. PLoS ONE 2015, 10, e0119946. [CrossRef]

26. Chen, J.; Raju, G.S.; Jogunoori, W.; Menon, V.; Majumdar, A.; Chen, J.S.; Gi, Y.J.; Jeong, Y.S.; Phan, L.; Belkin, M.; et al. Mutational profiles reveal an aberrant TGF-beta-CEA regulated pathway in colon adenomas. PLoS ONE 2016, 11, e0153933. [CrossRef]

27. Intarajak, T.; Udomchaiprasertkul, W.; Bunyoo, C.; Yimnoon, J.; Soonklang, K.; Wiriyaukaradecha, K.; Lamlertthon, W.; Sricharunrat, T.; Chaiwiriyawong, W.; Siriphongpreeda, B.; et al. Genetic aberration analysis in thai colorectal adenoma and early-stage adenocarcinoma patients by whole-exome sequencing. Cancers 2019, 11, 977. [CrossRef] [PubMed]

28. Lee, S.H.; Jung, S.H.; Kim, T.M.; Rhee, J.K.; Park, H.C.; Kim, M.S.; Kim, S.S.; An, C.H.; Lee, S.H.; Chung, Y.J. Whole-exome sequencing identified mutational profiles of high-grade colon adenomas. Oncotarget 2017, 8, 6579-6588. [CrossRef]

29. Yamada, M.; Sekine, S.; Ogawa, R.; Taniguchi, H.; Kushima, R.; Tsuda, H.; Kanai, Y. Frequent activating GNAS mutations in villous adenoma of the colorectum. J. Pathol. 2012, 228, 113-118. [CrossRef]

30. Yan, H.H.N.; Lai, J.C.W.; Ho, S.L.; Leung, W.K.; Law, W.L.; Lee, J.F.Y.; Chan, A.K.W.; Tsui, W.Y.; Chan, A.S.Y.; Lee, B.C.H.; et al. RNF43 germline and somatic mutation in serrated neoplasia pathway and its association with BRAF mutation. Gut 2017, 66, 1645-1656. [CrossRef] [PubMed]

31. Tsai, J.H.; Liau, J.Y.; Yuan, C.T.; Lin, Y.L.; Tseng, L.H.; Cheng, M.L.; Jeng, Y.M. RNF43 Is an Early and Specific Mutated Gene in the Serrated Pathway, With Increased Frequency in Traditional Serrated Adenoma and Its Associated Malignancy. Am. J. Surg. Pathol. 2016, 40, 1352-1359. [CrossRef] [PubMed]

32. Sekine, S.; Yamashita, S.; Tanabe, T.; Hashimoto, T.; Yoshida, H.; Taniguchi, H.; Kojima, M.; Shinmura, K.; Saito, Y.; Hiraoka, N.; et al. Frequent PTPRK-RSPO3 fusions and RNF43 mutations in colorectal traditional serrated adenoma. J. Pathol. 2016, 239, 133-138. [CrossRef] [PubMed]

33. Borowsky, J.; Dumenil, T.; Bettington, M.; Pearson, S.A.; Bond, C.; Fennell, L.; Liu, C.; McKeone, D.; Rosty, C.; Brown, I.; et al. The role of APC in WNT pathway activation in serrated neoplasia. Mod. Pathol. 2018, 31, 495-504. [CrossRef] [PubMed]

34. Hashimoto, T.; Yamashita, S.; Yoshida, H.; Taniguchi, H.; Ushijima, T.; Yamada, T.; Saito, Y.; Ochiai, A.; Sekine, S.; Hiraoka, N. WNT pathway gene mutations are associated with the presence of dysplasia in colorectal sessile serrated adenoma/polyps. Am. J. Surg. Pathol. 2017, 41, 1188-1197. [CrossRef] [PubMed]

35. Sekine, S.; Yamashita, S.; Yamada, M.; Hashimoto, T.; Ogawa, R.; Yoshida, H.; Taniguchi, H.; Kojima, M.; Ushijima, T.; Saito, Y. Clinicopathological and molecular correlations in traditional serrated adenoma. J. Gastroenterol. 2020, 55, 418-427. [CrossRef]

36. Alquati, C.; Prossomariti, A.; Piazzi, G.; Buttitta, F.; Bazzoli, F.; Laghi, L.; Ricciardiello, L. Discovering the mutational profile of early colorectal lesions: A translational impact. Cancers 2021, 13, 2081. [CrossRef] 
37. Steuer, C.E.; Ramalingam, S.S. Tumor Mutation Burden: Leading Immunotherapy to the Era of Precision Medicine? J. Clin. Oncol. 2018, 36, 631-632. [CrossRef] [PubMed]

38. Merino, D.M.; McShane, L.M.; Fabrizio, D.; Funari, V.; Chen, S.J.; White, J.R.; Wenz, P.; Baden, J.; Barrett, J.C.; Chaudhary, R.; et al. Establishing guidelines to harmonize tumor mutational burden (TMB): In silico assessment of variation in TMB quantification across diagnostic platforms: Phase I of the Friends of Cancer Research TMB Harmonization Project. J. Immunother. Cancer 2020, 8. [CrossRef]

39. Zhang, W.; Wang, R.; Fang, H.; Ma, X.; Li, D.; Liu, T.; Chen, Z.; Wang, K.; Hao, S.; Yu, Z.; et al. Influence of low tumor content on tumor mutational burden estimation by whole-exome sequencing and targeted panel sequencing. Clin. Transl. Med. 2021, 11, e415. [CrossRef] [PubMed]

40. Hodi, F.S.; O’Day, S.J.; McDermott, D.F.; Weber, R.W.; Sosman, J.A.; Haanen, J.B.; Gonzalez, R.; Robert, C.; Schadendorf, D.; Hassel, J.C.; et al. Improved survival with ipilimumab in patients with metastatic melanoma. N. Engl. J. Med. 2010, 363, 711-723. [CrossRef]

41. Borghaei, H.; Paz-Ares, L.; Horn, L.; Spigel, D.R.; Steins, M.; Ready, N.E.; Chow, L.Q.; Vokes, E.E.; Felip, E.; Holgado, E.; et al. Nivolumab versus Docetaxel in Advanced Nonsquamous Non-Small-Cell Lung Cancer. N. Engl. J. Med. 2015, 373, 1627-1639. [CrossRef] [PubMed]

42. Motzer, R.J.; Escudier, B.; McDermott, D.F.; George, S.; Hammers, H.J.; Srinivas, S.; Tykodi, S.S.; Sosman, J.A.; Procopio, G.; Plimack, E.R.; et al. Nivolumab versus Everolimus in Advanced Renal-Cell Carcinoma. N. Engl. J. Med. 2015, 373, 1803-1813. [CrossRef] [PubMed]

43. Rosenberg, J.E.; Hoffman-Censits, J.; Powles, T.; van der Heijden, M.S.; Balar, A.V.; Necchi, A.; Dawson, N.; O’Donnell, P.H.; Balmanoukian, A.; Loriot, Y.; et al. Atezolizumab in patients with locally advanced and metastatic urothelial carcinoma who have progressed following treatment with platinum-based chemotherapy: A single-arm, multicentre, phase 2 trial. Lancet 2016, 387, 1909-1920. [CrossRef]

44. Wolchok, J.D.; Kluger, H.; Callahan, M.K.; Postow, M.A.; Rizvi, N.A.; Lesokhin, A.M.; Segal, N.H.; Ariyan, C.E.; Gordon, R.A.; Reed, K.; et al. Nivolumab plus ipilimumab in advanced melanoma. N. Engl. J. Med. 2013, 369, 122-133. [CrossRef] [PubMed]

45. Motzer, R.J.; Tannir, N.M.; McDermott, D.F.; Arén Frontera, O.; Melichar, B.; Choueiri, T.K.; Plimack, E.R.; Barthélémy, P.; Porta, C.; George, S.; et al. Nivolumab plus Ipilimumab versus Sunitinib in Advanced Renal-Cell Carcinoma. N. Engl. J. Med. 2018, 378, 1277-1290. [CrossRef]

46. Antonia, S.J.; Villegas, A.; Daniel, D.; Vicente, D.; Murakami, S.; Hui, R.; Yokoi, T.; Chiappori, A.; Lee, K.H.; de Wit, M.; et al. Durvalumab after chemoradiotherapy in stage III non-small-cell lung cancer. N. Engl. J. Med. 2017, 377, 1919-1929. [CrossRef] [PubMed]

47. Nghiem, P.T.; Bhatia, S.; Lipson, E.J.; Kudchadkar, R.R.; Miller, N.J.; Annamalai, L.; Berry, S.; Chartash, E.K.; Daud, A.; Fling, S.P.; et al. PD-1 blockade with pembrolizumab in advanced merkel-cell carcinoma. N. Engl. J. Med. 2016, 374, 2542-2552. [CrossRef]

48. Andre, T.; Shiu, K.K.; Kim, T.W.; Jensen, B.V.; Jensen, L.H.; Punt, C.; Smith, D.; Garcia-Carbonero, R.; Benavides, M.; Gibbs, P.; et al. Pembrolizumab in Microsatellite-Instability-High Advanced Colorectal Cancer. N. Engl. J. Med. 2020, 383, 2207-2218. [CrossRef]

49. Innocenti, F.; Ou, F.S.; Qu, X.; Zemla, T.J.; Niedzwiecki, D.; Tam, R.; Mahajan, S.; Goldberg, R.M.; Bertagnolli, M.M.; Blanke, C.D.; et al. Mutational analysis of patients with colorectal cancer in CALGB/SWOG 80405 identifies new roles of microsatellite instability and tumor mutational burden for patient outcome. J. Clin. Oncol. 2019, 37, 1217-1227. [CrossRef]

50. Samstein, R.M.; Lee, C.H.; Shoushtari, A.N.; Hellmann, M.D.; Shen, R.; Janjigian, Y.Y.; Barron, D.A.; Zehir, A.; Jordan, E.J.; Omuro, A.; et al. Tumor mutational load predicts survival after immunotherapy across multiple cancer types. Nat. Genet. 2019, 51, 202-206. [CrossRef]

51. Cao, D.; Xu, H.; Xu, X.; Guo, T.; Ge, W. High tumor mutation burden predicts better efficacy of immunotherapy: A pooled analysis of 103078 cancer patients. Oncoimmunology 2019, 8, e1629258. [CrossRef] [PubMed]

52. Wu, H.X.; Wang, Z.X.; Zhao, Q.; Chen, D.L.; He, M.M.; Yang, L.P.; Wang, Y.N.; Jin, Y.; Ren, C.; Luo, H.Y.; et al. Tumor mutational and indel burden: A systematic pan-cancer evaluation as prognostic biomarkers. Ann. Transl. Med. 2019, 7, 640. [CrossRef]

53. Borras, E.; San Lucas, F.A.; Chang, K.; Zhou, R.; Masand, G.; Fowler, J.; Mork, M.E.; You, Y.N.; Taggart, M.W.; McAllister, F.; et al. Genomic Landscape of Colorectal Mucosa and Adenomas. Cancer Prev. Res. 2016, 9, 417-427. [CrossRef] [PubMed]

54. Karczmarski, J.; Goryca, K.; Pachlewski, J.; Dabrowska, M.; Pysniak, K.; Paziewska, A.; Kulecka, M.; Lenarcik, M.; Mroz, A.; Mikula, M.; et al. Mutation profiling of premalignant colorectal neoplasia. Gastroenterol. Res. Pract. 2019, 2019, 2542640. [CrossRef] [PubMed]

55. Matsushita, H.; Vesely, M.D.; Koboldt, D.C.; Rickert, C.G.; Uppaluri, R.; Magrini, V.J.; Arthur, C.D.; White, J.M.; Chen, Y.S.; Shea, L.K.; et al. Cancer exome analysis reveals a T-cell-dependent mechanism of cancer immunoediting. Nature 2012, 482, 400-404. [CrossRef] [PubMed]

56. Shankaran, V.; Ikeda, H.; Bruce, A.T.; White, J.M.; Swanson, P.E.; Old, L.J.; Schreiber, R.D. IFNgamma and lymphocytes prevent primary tumour development and shape tumour immunogenicity. Nature 2001, 410, 1107-1111. [CrossRef]

57. Koebel, C.M.; Vermi, W.; Swann, J.B.; Zerafa, N.; Rodig, S.J.; Old, L.J.; Smyth, M.J.; Schreiber, R.D. Adaptive immunity maintains occult cancer in an equilibrium state. Nature 2007, 450, 903-907. [CrossRef]

58. Galon, J.; Pages, F.; Marincola, F.M.; Angell, H.K.; Thurin, M.; Lugli, A.; Zlobec, I.; Berger, A.; Bifulco, C.; Botti, G.; et al. Cancer classification using the Immunoscore: A worldwide task force. J. Transl. Med. 2012, 10, 205. [CrossRef] 
59. Galon, J.; Angell, H.K.; Bedognetti, D.; Marincola, F.M. The continuum of cancer immunosurveillance: Prognostic, predictive, and mechanistic signatures. Immunity 2013, 39, 11-26. [CrossRef]

60. Mlecnik, B.; Tosolini, M.; Kirilovsky, A.; Berger, A.; Bindea, G.; Meatchi, T.; Bruneval, P.; Trajanoski, Z.; Fridman, W.H.; Pagès, F.; et al. Histopathologic-based prognostic factors of colorectal cancers are associated with the state of the local immune reaction. $J$. Clin. Oncol. 2011, 29, 610-618. [CrossRef]

61. Pages, F.; Kirilovsky, A.; Mlecnik, B.; Asslaber, M.; Tosolini, M.; Bindea, G.; Lagorce, C.; Wind, P.; Marliot, F.; Bruneval, P.; et al. In situ cytotoxic and memory $\mathrm{T}$ cells predict outcome in patients with early-stage colorectal cancer. J. Clin. Oncol. 2009, 27, 5944-5951. [CrossRef] [PubMed]

62. Acosta-Gonzalez, G.; Ouseph, M.; Lombardo, K.; Lu, S.; Glickman, J.; Resnick, M.B. Immune environment in serrated lesions of the colon: Intraepithelial lymphocyte density, PD-1, and PD-L1 expression correlate with serrated neoplasia pathway progression. Hum. Pathol. 2019, 83, 115-123. [CrossRef]

63. Murakami, T.; Mitomi, H.; Yao, T.; Saito, T.; Shibuya, T.; Sakamoto, N.; Osada, T.; Watanabe, S. Distinct histopathological characteristics in colorectal submucosal invasive carcinoma arising in sessile serrated adenoma/polyp and conventional tubular adenoma. Virchows Arch. 2018, 472, 383-393. [CrossRef] [PubMed]

64. Yuan, A.; Steigen, S.E.; Goll, R.; Vonen, B.; Husbekk, A.; Cui, G.; Florholmen, J. Dendritic cell infiltration pattern along the colorectal adenoma-carcinoma sequence. APMIS Acta Pathol. Microbiol. Immunol. Scand. 2008, 116, 445-456. [CrossRef] [PubMed]

65. Dunne, M.R.; Phelan, J.J.; Michielsen, A.J.; Maguire, A.A.; Dunne, C.; Martin, P.; Noonan, S.; Tosetto, M.; Geraghty, R.; Fennelly, D.; et al. Characterising the prognostic potential of HLA-DR during colorectal cancer development. Cancer Immunol. Immunother. 2020, 69, 1577-1588. [CrossRef]

66. Wu, Q.B.; Sun, G.P. Expression of COX-2 and HER-2 in colorectal cancer and their correlation. World J. Gastroenterol. 2015, 21, 6206-6214. [CrossRef]

67. Peyravian, N.; Gharib, E.; Moradi, A.; Mobahat, M.; Tarban, P.; Azimzadeh, P.; Nazemalhosseini-Mojarad, E.; Asadzadeh Aghdaei, H. Evaluating the expression level of co-stimulatory molecules CD 80 and CD 86 in different types of colon polyps. Curr. Res. Transl. Med. 2018, 66, 19-25. [CrossRef]

68. Enarsson, K.; Lundin, B.S.; Johnsson, E.; Brezicka, T.; Quiding-Jarbrink, M. CD4+ CD25high regulatory T cells reduce T cell transendothelial migration in cancer patients. Eur. J. Immunol. 2007, 37, 282-291. [CrossRef]

69. Sundstrom, P.; Stenstad, H.; Langenes, V.; Ahlmanner, F.; Theander, L.; Ndah, T.G.; Fredin, K.; Borjesson, L.; Gustavsson, B.; Bastid, J.; et al. Regulatory T cells from colon cancer patients inhibit effector T-cell migration through an adenosine-dependent mechanism. Cancer Immunol. Res. 2016, 4, 183-193. [CrossRef]

70. Svensson, H.; Olofsson, V.; Lundin, S.; Yakkala, C.; Bjorck, S.; Borjesson, L.; Gustavsson, B.; Quiding-Jarbrink, M. Accumulation of CCR4(+)CTLA-4 FOXP3(+)CD25(hi) regulatory T cells in colon adenocarcinomas correlate to reduced activation of conventional T cells. PLoS ONE 2012, 7, e30695. [CrossRef]

71. Ahlmanner, F.; Sundstrom, P.; Akeus, P.; Eklof, J.; Borjesson, L.; Gustavsson, B.; Lindskog, E.B.; Raghavan, S.; Quiding-Jarbrink, M. CD39(+) regulatory T cells accumulate in colon adenocarcinomas and display markers of increased suppressive function. Oncotarget 2018, 9, 36993-37007. [CrossRef]

72. Yaqub, S.; Henjum, K.; Mahic, M.; Jahnsen, F.L.; Aandahl, E.M.; Bjornbeth, B.A.; Tasken, K. Regulatory T cells in colorectal cancer patients suppress anti-tumor immune activity in a COX-2 dependent manner. Cancer Immunol. Immunother. 2008, 57, 813-821. [CrossRef]

73. Rubinkiewicz, M.; Migaczewski, M.; Hankus, J.; Dembinski, M.; Pedziwiatr, M.; Okon, K.; Pisarska, M.; Budzynski, A. The number of regulatory Foxp3+ T-cells in different stages of malignant transformation of large intestinal polyps. Adv. Med. Sci. 2016, 61, 306-310. [CrossRef]

74. Zhu, X.W.; Zhu, H.Z.; Zhu, Y.Q.; Feng, M.H.; Qi, J.; Chen, Z.F. Foxp3 expression in CD4(+)CD25(+)Foxp3(+) regulatory T cells promotes development of colorectal cancer by inhibiting tumor immunity. J. Huazhong Univ. Sci. Technol. 2016, 36, 677-682. [CrossRef]

75. Garcia, D.; Spaans, L.; Miranda, S.; Goncalves, G.; Reis, J.; Costa, J.L.; Duraes, C.; Carneiro, F.; Machado, J.C. The influence of the genetic and immunologic context in the development of colorectal adenoma: A case series report. Acta Med. Port. 2020, 33, 297-304. [CrossRef] [PubMed]

76. Hua, W.; Yuan, A.; Zheng, W.; Li, C.; Cui, J.; Pang, Z.; Zhang, L.; Li, Z.; Goll, R.; Cui, G. Accumulation of FoxP3+ T regulatory cells in the tumor microenvironment of human colorectal adenomas. Pathol. Res. Pract. 2016, 212, 106-112. [CrossRef] [PubMed]

77. Johdi, N.A.; Ait-Tahar, K.; Sagap, I.; Jamal, R. Molecular signatures of human regulatory T cells in colorectal cancer and polyps. Front. Immunol. 2017, 8, 620. [CrossRef]

78. Cui, G.; Yang, H.; Zhao, J.; Yuan, A.; Florholmen, J. Elevated proinflammatory cytokine IL-17A in the adjacent tissues along the adenoma-carcinoma sequence. Pathol. Oncol. Res. 2015, 21, 139-146. [CrossRef]

79. Cui, G.; Yuan, A.; Goll, R.; Florholmen, J. IL-17A in the tumor microenvironment of the human colorectal adenoma-carcinoma sequence. Scand. J. Gastroenterol. 2012, 47, 1304-1312. [CrossRef] [PubMed]

80. Xie, Z.; Qu, Y.; Leng, Y.; Sun, W.; Ma, S.; Wei, J.; Hu, J.; Zhang, X. Human colon carcinogenesis is associated with increased interleukin-17-driven inflammatory responses. Drug Des. Devel. Ther. 2015, 9, 1679-1689. [CrossRef]

81. Cui, G.; Goll, R.; Olsen, T.; Steigen, S.E.; Husebekk, A.; Vonen, B.; Florholmen, J. Reduced expression of microenvironmental Th1 cytokines accompanies adenomas-carcinomas sequence of colorectum. Cancer Immunol. Immunother. 2007, 56, 985-995. [CrossRef] 
82. Tosolini, M.; Kirilovsky, A.; Mlecnik, B.; Fredriksen, T.; Mauger, S.; Bindea, G.; Berger, A.; Bruneval, P.; Fridman, W.H.; Pages, F.; et al. Clinical impact of different classes of infiltrating T cytotoxic and helper cells (Th1, th2, treg, th17) in patients with colorectal cancer. Cancer Res. 2011, 71, 1263-1271. [CrossRef]

83. Contasta, I.; Berghella, A.M.; Pellegrini, P.; Adorno, D. Passage from normal mucosa to adenoma and colon cancer: Alteration of normal sCD30 mechanisms regulating TH1/TH2 cell functions. Cancer Biother. Radiopharm. 2003, 18, 549-557. [CrossRef] [PubMed]

84. Pellegrini, P.; Berghella, A.M.; Del Beato, T.; Cicia, S.; Adorno, D.; Casciani, C.U. Disregulation in TH1 and TH2 subsets of CD4+ T cells in peripheral blood of colorectal cancer patients and involvement in cancer establishment and progression. Cancer Immunol. Immunother. 1996, 42, 1-8. [CrossRef] [PubMed]

85. Forssell, J.; Oberg, A.; Henriksson, M.L.; Stenling, R.; Jung, A.; Palmqvist, R. High macrophage infiltration along the tumor front correlates with improved survival in colon cancer. Clin. Cancer Res. 2007, 13, 1472-1479. [CrossRef]

86. Zhou, Q.; Peng, R.Q.; Wu, X.J.; Xia, Q.; Hou, J.H.; Ding, Y.; Zhou, Q.M.; Zhang, X.; Pang, Z.Z.; Wan, D.S.; et al. The density of macrophages in the invasive front is inversely correlated to liver metastasis in colon cancer. J. Transl. Med. 2010, 8, 13. [CrossRef]

87. Wikberg, M.L.; Ling, A.; Li, X.; Oberg, A.; Edin, S.; Palmqvist, R. Neutrophil infiltration is a favorable prognostic factor in early stages of colon cancer. Hum. Pathol. 2017, 68, 193-202. [CrossRef] [PubMed]

88. Halama, N.; Braun, M.; Kahlert, C.; Spille, A.; Quack, C.; Rahbari, N.; Koch, M.; Weitz, J.; Kloor, M.; Zoernig, I.; et al. Natural killer cells are scarce in colorectal carcinoma tissue despite high levels of chemokines and cytokines. Clin. Cancer Res. 2011, 17, 678-689. [CrossRef]

89. Coca, S.; Perez-Piqueras, J.; Martinez, D.; Colmenarejo, A.; Saez, M.A.; Vallejo, C.; Martos, J.A.; Moreno, M. The prognostic significance of intratumoral natural killer cells in patients with colorectal carcinoma. Cancer 1997, 79, 2320-2328. [CrossRef]

90. Jayakumar, A.; Bothwell, A.L.M. Stat6 Promotes Intestinal Tumorigenesis in a Mouse Model of Adenomatous Polyposis by Expansion of MDSCs and Inhibition of Cytotoxic CD8 Response. Neoplasia 2017, 19, 595-605. [CrossRef] [PubMed]

91. Chun, E.; Lavoie, S.; Michaud, M.; Gallini, C.A.; Kim, J.; Soucy, G.; Odze, R.; Glickman, J.N.; Garrett, W.S. CCL2 Promotes colorectal carcinogenesis by enhancing polymorphonuclear myeloid-derived suppressor cell population and function. Cell Rep. 2015, 12, 244-257. [CrossRef] [PubMed]

92. Wang, Y.; Sedimbi, S.; Lofbom, L.; Singh, A.K.; Porcelli, S.A.; Cardell, S.L. Unique invariant natural killer T cells promote intestinal polyps by suppressing TH1 immunity and promoting regulatory T cells. Mucosal Immunol. 2018, 11, 131-143. [CrossRef] [PubMed]

93. Wang, Y.; Sedimbi, S.K.; Lofbom, L.; Besra, G.S.; Porcelli, S.A.; Cardell, S.L. Promotion or suppression of murine intestinal polyp development by iNKT cell directed immunotherapy. Front. Immunol. 2019, 10, 352. [CrossRef] [PubMed]

94. Galon, J.; Bruni, D. Tumor Immunology and Tumor Evolution: Intertwined Histories. Immunity 2020, 52, 55-81. [CrossRef]

95. Idos, G.E.; Kwok, J.; Bonthala, N.; Kysh, L.; Gruber, S.B.; Qu, C. The prognostic implications of tumor infiltrating lymphocytes in colorectal cancer: A systematic review and meta-analysis. Sci. Rep. 2020, 10, 3360. [CrossRef]

96. Zhao, Y.; Ge, X.; He, J.; Cheng, Y.; Wang, Z.; Wang, J.; Sun, L. The prognostic value of tumor-infiltrating lymphocytes in colorectal cancer differs by anatomical subsite: A systematic review and meta-analysis. World J. Surg. Oncol. 2019, 17, 85. [CrossRef] [PubMed]

97. Salama, P.; Phillips, M.; Grieu, F.; Morris, M.; Zeps, N.; Joseph, D.; Platell, C.; Iacopetta, B. Tumor-infiltrating FOXP3+ T regulatory cells show strong prognostic significance in colorectal cancer. J. Clin. Oncol. 2009, 27, 186-192. [CrossRef]

98. Sundstrom, P.; Ahlmanner, F.; Akeus, P.; Sundquist, M.; Alsen, S.; Yrlid, U.; Borjesson, L.; Sjoling, A.; Gustavsson, B.; Wong, S.B.; et al. Human mucosa-associated invariant T cells accumulate in colon adenocarcinomas but produce reduced amounts of IFN-gamma. J. Immunol. 2015, 195, 3472-3481. [CrossRef]

99. Tachibana, T.; Onodera, H.; Tsuruyama, T.; Mori, A.; Nagayama, S.; Hiai, H.; Imamura, M. Increased intratumor Valpha24-positive natural killer T cells: A prognostic factor for primary colorectal carcinomas. Clin. Cancer Res. 2005, 11, 7322-7327. [CrossRef] [PubMed]

100. Edin, S.; Kaprio, T.; Hagstrom, J.; Larsson, P.; Mustonen, H.; Bockelman, C.; Strigard, K.; Gunnarsson, U.; Haglund, C.; Palmqvist, R. The Prognostic Importance of CD20(+) B lymphocytes in Colorectal Cancer and the Relation to Other Immune Cell subsets. Sci. Rep. 2019, 9, 19997. [CrossRef] [PubMed]

101. Bauer, K.; Michel, S.; Reuschenbach, M.; Nelius, N.; von Knebel Doeberitz, M.; Kloor, M. Dendritic cell and macrophage infiltration in microsatellite-unstable and microsatellite-stable colorectal cancer. Fam. Cancer 2011, 10, 557-565. [CrossRef]

102. Nagorsen, D.; Voigt, S.; Berg, E.; Stein, H.; Thiel, E.; Loddenkemper, C. Tumor-infiltrating macrophages and dendritic cells in human colorectal cancer: Relation to local regulatory $\mathrm{T}$ cells, systemic T-cell response against tumor-associated antigens and survival. J. Transl. Med. 2007, 5, 62. [CrossRef] [PubMed]

103. Costello, E.K.; Lauber, C.L.; Hamady, M.; Fierer, N.; Gordon, J.I.; Knight, R. Bacterial community variation in human body habitats across space and time. Science 2009, 326, 1694-1697. [CrossRef]

104. Conlon, M.A.; Bird, A.R. The impact of diet and lifestyle on gut microbiota and human health. Nutrients 2014, 7, 17-44. [CrossRef]

105. David, L.A.; Maurice, C.F.; Carmody, R.N.; Gootenberg, D.B.; Button, J.E.; Wolfe, B.E.; Ling, A.V.; Devlin, A.S.; Varma, Y.; Fischbach, M.A.; et al. Diet rapidly and reproducibly alters the human gut microbiome. Nature 2014, 505, 559-563. [CrossRef] [PubMed] 
106. Wu, G.D.; Chen, J.; Hoffmann, C.; Bittinger, K.; Chen, Y.Y.; Keilbaugh, S.A.; Bewtra, M.; Knights, D.; Walters, W.A.; Knight, R.; et al. Linking long-term dietary patterns with gut microbial enterotypes. Science 2011, 334, 105-108. [CrossRef]

107. Arumugam, M.; Raes, J.; Pelletier, E.; Le Paslier, D.; Yamada, T.; Mende, D.R.; Fernandes, G.R.; Tap, J.; Bruls, T.; Batto, J.M.; et al. Enterotypes of the human gut microbiome. Nature 2011, 473, 174-180. [CrossRef] [PubMed]

108. Feng, Q.; Liang, S.; Jia, H.; Stadlmayr, A.; Tang, L.; Lan, Z.; Zhang, D.; Xia, H.; Xu, X.; Jie, Z.; et al. Gut microbiome development along the colorectal adenoma-carcinoma sequence. Nat. Commun. 2015, 6, 6528. [CrossRef]

109. Durban, A.; Abellan, J.J.; Jimenez-Hernandez, N.; Ponce, M.; Ponce, J.; Sala, T.; D'Auria, G.; Latorre, A.; Moya, A. Assessing gut microbial diversity from feces and rectal mucosa. Microb. Ecol. 2011, 61, 123-133. [CrossRef]

110. Ringel, Y.; Maharshak, N.; Ringel-Kulka, T.; Wolber, E.A.; Sartor, R.B.; Carroll, I.M. High throughput sequencing reveals distinct microbial populations within the mucosal and luminal niches in healthy individuals. Gut Microbes 2015, 6, 173-181. [CrossRef]

111. Pleguezuelos-Manzano, C.; Puschhof, J.; Rosendahl Huber, A.; van Hoeck, A.; Wood, H.M.; Nomburg, J.; Gurjao, C.; Manders, F.; Dalmasso, G.; Stege, P.B.; et al. Mutational signature in colorectal cancer caused by genotoxic pks(+) E. coli. Nature 2020, 580, 269-273. [CrossRef]

112. Shen, X.J.; Rawls, J.F.; Randall, T.; Burcal, L.; Mpande, C.N.; Jenkins, N.; Jovov, B.; Abdo, Z.; Sandler, R.S.; Keku, T.O. Molecular characterization of mucosal adherent bacteria and associations with colorectal adenomas. Gut Microbes 2010, 1, 138-147. [CrossRef]

113. Mangifesta, M.; Mancabelli, L.; Milani, C.; Gaiani, F.; de'Angelis, N.; de'Angelis, G.L.; van Sinderen, D.; Ventura, M.; Turroni, F. Mucosal microbiota of intestinal polyps reveals putative biomarkers of colorectal cancer. Sci. Rep. 2018, 8, 13974. [CrossRef] [PubMed]

114. Sanapareddy, N.; Legge, R.M.; Jovov, B.; McCoy, A.; Burcal, L.; Araujo-Perez, F.; Randall, T.A.; Galanko, J.; Benson, A.; Sandler, R.S.; et al. Increased rectal microbial richness is associated with the presence of colorectal adenomas in humans. ISME J. 2012, 6, 1858-1868. [CrossRef]

115. Wang, W.J.; Zhou, Y.L.; He, J.; Feng, Z.Q.; Zhang, L.; Lai, X.B.; Zhou, J.X.; Wang, H. Characterizing the composition of intestinal microflora by $16 \mathrm{~S}$ rRNA gene sequencing. World J. Gastroenterol. 2020, 26, 614-626. [CrossRef]

116. Dadkhah, E.; Sikaroodi, M.; Korman, L.; Hardi, R.; Baybick, J.; Hanzel, D.; Kuehn, G.; Kuehn, T.; Gillevet, P.M. Gut microbiome identifies risk for colorectal polyps. BMJ Open Gastroenterol. 2019, 6, e000297. [CrossRef] [PubMed]

117. Nugent, J.L.; McCoy, A.N.; Addamo, C.J.; Jia, W.; Sandler, R.S.; Keku, T.O. Altered tissue metabolites correlate with microbial dysbiosis in colorectal adenomas. J. Proteome Res. 2014, 13, 1921-1929. [CrossRef]

118. Shang, F.M.; Liu, H.L. Fusobacterium nucleatum and colorectal cancer: A review. World J. Gastrointest. Oncol. 2018, 10, 71-81. [CrossRef] [PubMed]

119. McCoy, A.N.; Araujo-Perez, F.; Azcarate-Peril, A.; Yeh, J.J.; Sandler, R.S.; Keku, T.O. Fusobacterium is associated with colorectal adenomas. PLoS ONE 2013, 8, e53653. [CrossRef] [PubMed]

120. Kostic, A.D.; Chun, E.; Robertson, L.; Glickman, J.N.; Gallini, C.A.; Michaud, M.; Clancy, T.E.; Chung, D.C.; Lochhead, P.; Hold, G.L.; et al. Fusobacterium nucleatum potentiates intestinal tumorigenesis and modulates the tumor-immune microenvironment. Cell Host Microbe 2013, 14, 207-215. [CrossRef]

121. Ito, M.; Kanno, S.; Nosho, K.; Sukawa, Y.; Mitsuhashi, K.; Kurihara, H.; Igarashi, H.; Takahashi, T.; Tachibana, M.; Takahashi, H.; et al. Association of Fusobacterium nucleatum with clinical and molecular features in colorectal serrated pathway. Int. J. Cancer 2015, 137, 1258-1268. [CrossRef]

122. Yoon, H.; Kim, N.; Park, J.H.; Kim, Y.S.; Lee, J.; Kim, H.W.; Choi, Y.J.; Shin, C.M.; Park, Y.S.; Lee, D.H.; et al. Comparisons of gut microbiota among healthy control, patients with conventional adenoma, sessile serrated adenoma, and colorectal cancer. J. Cancer Prev. 2017, 22, 108-114. [CrossRef]

123. Tjalsma, H.; Boleij, A.; Marchesi, J.R.; Dutilh, B.E. A bacterial driver-passenger model for colorectal cancer: Beyond the usual suspects. Nat. Rev. Microbiol. 2012, 10, 575-582. [CrossRef]

124. Bridges, K.M.; Greiner, K.A.; Umar, S. Deciphering the colorectal cancer gut microbiota: Association vs. causality. Curr. Colorect. Canc. R. 2019, 15, 70-77. [CrossRef]

125. Huse, S.M.; Dethlefsen, L.; Huber, J.A.; Mark Welch, D.; Relman, D.A.; Sogin, M.L. Exploring microbial diversity and taxonomy using SSU rRNA hypervariable tag sequencing. PLoS Genet. 2008, 4, e1000255. [CrossRef]

126. Mignard, S.; Flandrois, J.P. $16 \mathrm{~S}$ rRNA sequencing in routine bacterial identification: A 30-month experiment. J. Microbiol. Methods 2006, 67, 574-581. [CrossRef]

127. Nicholson, J.K.; Holmes, E.; Kinross, J.; Burcelin, R.; Gibson, G.; Jia, W.; Pettersson, S. Host-gut microbiota metabolic interactions. Science 2012, 336, 1262-1267. [CrossRef] [PubMed]

128. Louis, P.; Hold, G.L.; Flint, H.J. The gut microbiota, bacterial metabolites and colorectal cancer. Nat. Rev. Microbiol. 2014, 12, 661-672. [CrossRef] [PubMed]

129. Mira-Pascual, L.; Cabrera-Rubio, R.; Ocon, S.; Costales, P.; Parra, A.; Suarez, A.; Moris, F.; Rodrigo, L.; Mira, A.; Collado, M.C. Microbial mucosal colonic shifts associated with the development of colorectal cancer reveal the presence of different bacterial and archaeal biomarkers. J. Gastroenterol. 2015, 50, 167-179. [CrossRef]

130. Lu, Y.; Chen, J.; Zheng, J.; Hu, G.; Wang, J.; Huang, C.; Lou, L.; Wang, X.; Zeng, Y. Mucosal adherent bacterial dysbiosis in patients with colorectal adenomas. Sci. Rep. 2016, 6, 26337. [CrossRef]

131. Coussens, L.M.; Werb, Z. Inflammation and cancer. Nature 2002, 420, 860-867. [CrossRef] [PubMed] 
132. Eaden, J.A.; Abrams, K.R.; Mayberry, J.F. The risk of colorectal cancer in ulcerative colitis: A meta-analysis. Gut 2001, $48,526-535$. [CrossRef]

133. Arthur, J.C.; Perez-Chanona, E.; Mühlbauer, M.; Tomkovich, S.; Uronis, J.M.; Fan, T.J.; Campbell, B.J.; Abujamel, T.; Dogan, B.; Rogers, A.B.; et al. Intestinal inflammation targets cancer-inducing activity of the microbiota. Science 2012, 338, 120-123. [CrossRef] [PubMed]

134. Dennis, K.L.; Wang, Y.; Blatner, N.R.; Wang, S.; Saadalla, A.; Trudeau, E.; Roers, A.; Weaver, C.T.; Lee, J.J.; Gilbert, J.A.; et al. Adenomatous polyps are driven by microbe-instigated focal inflammation and are controlled by IL-10-producing T cells. Cancer Res. 2013, 73, 5905-5913. [CrossRef] [PubMed]

135. Tomkovich, S.; Yang, Y.; Winglee, K.; Gauthier, J.; Muhlbauer, M.; Sun, X.; Mohamadzadeh, M.; Liu, X.; Martin, P.; Wang, G.P.; et al. Locoregional effects of microbiota in a preclinical model of colon carcinogenesis. Cancer Res. 2017, 77, 2620-2632. [CrossRef]

136. Huycke, M.M.; Joyce, W.; Wack, M.F. Augmented production of extracellular superoxide by blood isolates of Enterococcus faecalis. J. Infect. Dis. 1996, 173, 743-746. [CrossRef]

137. Ruiz, P.A.; Shkoda, A.; Kim, S.C.; Sartor, R.B.; Haller, D. IL-10 gene-deficient mice lack TGF-beta/Smad signaling and fail to inhibit proinflammatory gene expression in intestinal epithelial cells after the colonization with colitogenic Enterococcus faecalis. J. Immunol. 2005, 174, 2990-2999. [CrossRef]

138. Obiso, R.J., Jr.; Azghani, A.O.; Wilkins, T.D. The Bacteroides fragilis toxin fragilysin disrupts the paracellular barrier of epithelial cells. Infect. Immun. 1997, 65, 1431-1439. [CrossRef]

139. Wu, S.; Rhee, K.J.; Albesiano, E.; Rabizadeh, S.; Wu, X.; Yen, H.R.; Huso, D.L.; Brancati, F.L.; Wick, E.; McAllister, F.; et al. A human colonic commensal promotes colon tumorigenesis via activation of T helper type $17 \mathrm{~T}$ cell responses. Nat. Med. 2009, 15, 1016-1022. [CrossRef]

140. Geis, A.L.; Fan, H.; Wu, X.; Wu, S.; Huso, D.L.; Wolfe, J.L.; Sears, C.L.; Pardoll, D.M.; Housseau, F. Regulatory T-cell response to enterotoxigenic bacteroides fragilis colonization triggers IL17-dependent colon carcinogenesis. Cancer Discov. 2015, 5, 1098-1109. [CrossRef]

141. Yang, Y.; Weng, W.; Peng, J.; Hong, L.; Yang, L.; Toiyama, Y.; Gao, R.; Liu, M.; Yin, M.; Pan, C.; et al. Fusobacterium nucleatum increases proliferation of colorectal cancer cells and tumor development in mice by activating toll-like receptor 4 signaling to nuclear factor-kappaB, and up-regulating expression of MicroRNA-21. Gastroenterology 2017, 152, 851-866.e824. [CrossRef]

142. Rubinstein, M.R.; Wang, X.; Liu, W.; Hao, Y.; Cai, G.; Han, Y.W. Fusobacterium nucleatum promotes colorectal carcinogenesis by modulating E-cadherin/beta-catenin signaling via its FadA adhesin. Cell Host Microbe 2013, 14, 195-206. [CrossRef]

143. Gur, C.; Ibrahim, Y.; Isaacson, B.; Yamin, R.; Abed, J.; Gamliel, M.; Enk, J.; Bar-On, Y.; Stanietsky-Kaynan, N.; Coppenhagen-Glazer, S.; et al. Binding of the Fap2 protein of Fusobacterium nucleatum to human inhibitory receptor TIGIT protects tumors from immune cell attack. Immunity 2015, 42, 344-355. [CrossRef]

144. Biarc, J.; Nguyen, I.S.; Pini, A.; Gosse, F.; Richert, S.; Thierse, D.; Van Dorsselaer, A.; Leize-Wagner, E.; Raul, F.; Klein, J.P.; et al. Carcinogenic properties of proteins with pro-inflammatory activity from Streptococcus infantarius (formerly S.bovis). Carcinogenesis 2004, 25, 1477-1484. [CrossRef]

145. Raisch, J.; Rolhion, N.; Dubois, A.; Darfeuille-Michaud, A.; Bringer, M.A. Intracellular colon cancer-associated Escherichia coli promote protumoral activities of human macrophages by inducing sustained COX-2 expression. Lab. Investig. 2015, 95, 296-307. [CrossRef] [PubMed]

146. Grivennikov, S.I.; Wang, K.; Mucida, D.; Stewart, C.A.; Schnabl, B.; Jauch, D.; Taniguchi, K.; Yu, G.Y.; Osterreicher, C.H.; Hung, K.E.; et al. Adenoma-linked barrier defects and microbial products drive IL-23/IL-17-mediated tumour growth. Nature 2012, 491, 254-258. [CrossRef]

147. Grivennikov, S.; Karin, E.; Terzic, J.; Mucida, D.; Yu, G.Y.; Vallabhapurapu, S.; Scheller, J.; Rose-John, S.; Cheroutre, H.; Eckmann, L.; et al. IL-6 and Stat3 are required for survival of intestinal epithelial cells and development of colitis-associated cancer. Cancer Cell 2009, 15, 103-113. [CrossRef] [PubMed]

148. Aceto, G.M.; Catalano, T.; Curia, M.C. Molecular aspects of colorectal adenomas: The interplay among microenvironment, oxidative stress, and predisposition. Biomed. Res. Int. 2020, 2020, 1726309. [CrossRef]

149. Chen, J.; Pitmon, E.; Wang, K. Microbiome, inflammation and colorectal cancer. Semin. Immunol. 2017, 32, 43-53. [CrossRef] [PubMed] 